${ }^{\circledR}$ Entomologica Fennica. 26 October 1998

\title{
A revision of grassflies of the tribe Chloropini (Diptera, Chloropidae) of Finland, Estonia and North-West Russia
}

\author{
Emilia P. Nartshuk
}

Nartshuk, E. P. 1998: A revision of grassflies of the tribe Chloropini (Diptera, Chloropidae) of Finland, Estonia and North-West Russia. - Entomol. Fennica 9: 153-183.

Collections of Chloropini: genera Chlorops Meigen, Epichlorops Becker and Melanum Becker from Finland, Estonia, Karelia and the Kola Peninsula are revised. 24 species are recorded from Finland, 21 for Karelia and 8 for the Kola Peninsula. Three species of Chlorops for Finland, 3 for Estonia, 21 for Karelia and 8 for Murmansk oblast are recorded for the first time. The northern limits of distribution of Chlorops species are compared with the isopleths of effective temperature sums. A correlation between the distribution of Chlorops species northward and eastward in the Palaearctic is discussed. New synonymy: Chlorops laevicollis Becker, $1910=$ Oscinis scutellaris Zetterstedt, 1848 is established. The lectotype of Chlorops freyi Duda, 1933 is designated. A key to the known species from Finland, Estonia, Karelia, the Kola Peninsula and St. Petersburg region, maps of records in Finland, Karelia and the Kola Peninsula for all species, and an illustration of male genitalia for some species are provided.

Emilia Nartshuk, Zoological Institute, Russian Academy of Sciences, 199034, St. Petersburg, Universitetskaya nab. 1, Russia.

Received 15 February 1995, accepted 25 September 1997

\section{Introduction}

The tribe Chloropini includes 5 genera in the $\mathrm{Pa}$ laeartic fauna: Chlorops Meigen, Epichlorops Becker, Melanum Becker, Parectecephala Becker and Capnoptera Loew. Chlorops is the largest genus of the tribe and one of the largest in the family Chloropidae. The genus is worldwide and consists of more 200 species, the most species being known from the Holarctic, especially from the $\mathrm{Pa}$ laearctic (109 species). The genus Chlorops is represented in the North Palaearctic by many species, each from other genera of the tribe contains only one species. Genus Capnoptera makes an exception, but it is a Mediterranean genus.

No comprehensive study of the Chloropini of Finland has recently been published. Only one species of the genus Chlorops was recorded from Finland by Zetterstedt (1860). Later one species was described by Frey (1909). Duda (1933) studied the Finnish collection in the Zoological Museum of the University of Helsinki and described two new species of Chlorops from Finland. The list of known species was published by Frey (1933, 1941) and recently by Hackman (1980). A total of 21 species of the tribe were listed by Hackman. It is possible to find some meagre ecological data in the papers of Frey $(1909,1933)$, Krogerus $(1932$, 
1960) and Lindberg and Saris (1952).

The Chloropini of the St. Petersburg regions and Estonia have been fairly well studied (Stackelberg 1958, 1965, Nartshuk 1962, 1984, Nartshuk \& Elberg 1979). There have been no specific investigations on the Chloropini of Karelia and the Kola Peninsula. Some data were published by Frey (1933) and one species from Karelia has been described by Duda (1933).

\section{Material}

The present revision is based on extensive material from Finland, Karelia and the Kola Peninsula deposited in the Zoological Museum of the University of Helsinki (ZMH), and in the Zoological Institute of the Russian Academy of Sciences in St. Petersburg (ZIN), including material collected by the author in Estonia, the St. Petersburg region, and Espoo in Finland in 1985. Some material from Finland and Estonia was kindly sent to me by Dr. M. Koponen (Department of Applied Zoology of the University of Helsinki). A total of more than 1800 specimens from Finland, Karelia and the Kola Peninsula were investigated, of which over 1300 were collected at many localities in Finland (see maps in Appendix). Some additional material from the St. Petersburg region and Estonia was examined.

Type-specimens of the following species of Chlorops were investigated in the process of preparing this paper: Assuania distinguenda Frey, $O s$ cinis freyi Duda, O. bipunctus Duda (ZMH), Chlorops laevicollis Becker (ZIN), C. rufescens Oldenberg (formerly Deutsche Entomologische Institut in Eberswalde).

\section{Distribution of species}

New faunistic and distributional information is presented in this paper. Five species new to Finland have been detected: Chlorops centromaculatus (Duda), C. crassipalpis Smirnov, C. rossicus Smirnov, $C$. serenus Loew, $C$. zonulatus Wahlgren. On the other hand, three species have to be deleted from the check-list of Finnish Chloropidae. C. geminatus Meigen and C. figuratus Zetterstedt were not actually found in Finland and all specimens identified as these species belong to C. zonulatus. C. triangularis Becker is considered here only as a colour variation of $C$. planifrons Loew. Consequently, 22 species of Chlorops and one species each of Melanum and Epichlorops are realiably known from present-day Finland. To draw conclusions from the Chloropini found in Karelia, the St. Petersburg region and Estonia, at last five further species from this tribe may also be expected to be found in Finland, namely $C$. anthracophagoideus Strobl, C. laetus Meigen, C. nigripalpis (Duda), C. zernyi (Duda) and C. geminatus Meigen.

In this paper 21 species of the tribe Chloropini are recorded for Karelia and 8 species for the Kola Peninsula (Murmansk Region). Some species were previously recorded for these parts of Russia by Frey (1933) and one species by Duda (1933).

A comparison of the Chloropini fauna of Finland, Estonia and North-West Russia (St. Petersburg region, Karelia and the Kola Peninsula) is given in the table. The fauna of Yakutia (Nartshuk $1992 \mathrm{~b}$ ) is also included in this table to compare the Chloropini fauna of the western and eastern parts of the Palaearctic. Western and eastern parts of the compared territories are situated nearly at the same latitudes: the western between $57^{\circ} 30^{\prime}-$ $70^{\circ} \mathrm{N}$. and the eastern between $55^{\circ}-71^{\circ} 30^{\prime} \mathrm{N}$. However, the areas of the compared territories differ significantly, the western being 738,800 sq. km, and the eastern $3,162,100$ sq. km. Nevertheless the Choloropini fauna in the western part of the Palaearctic is to a great extent richer than the fauna in the eastern part at the same latitude in the boreal zone.

The fauna of the territory in question is rather young and has been formed by migrations from different refuges after the end of the glacial period during the last $10-12,000$ years. Consequently, a comparison of the Chloropini lists of the St. Petersburg region, Estonia, Karelia and the Kola Peninsula enables one to discuss the northern limit of the ranges of some species. It is possible to see from the map (Fig. 1) that the number of Chlorops species decreases from 13-15 in southern Finland to 1-3 in the northern part of the country. This decline is rather gradual in Chlorops but sharper in Meromyza Meigen (Fig. 2). The latter genus of the Chloropidae is also rather large, including phytophagous larvae as does Chlorops, 


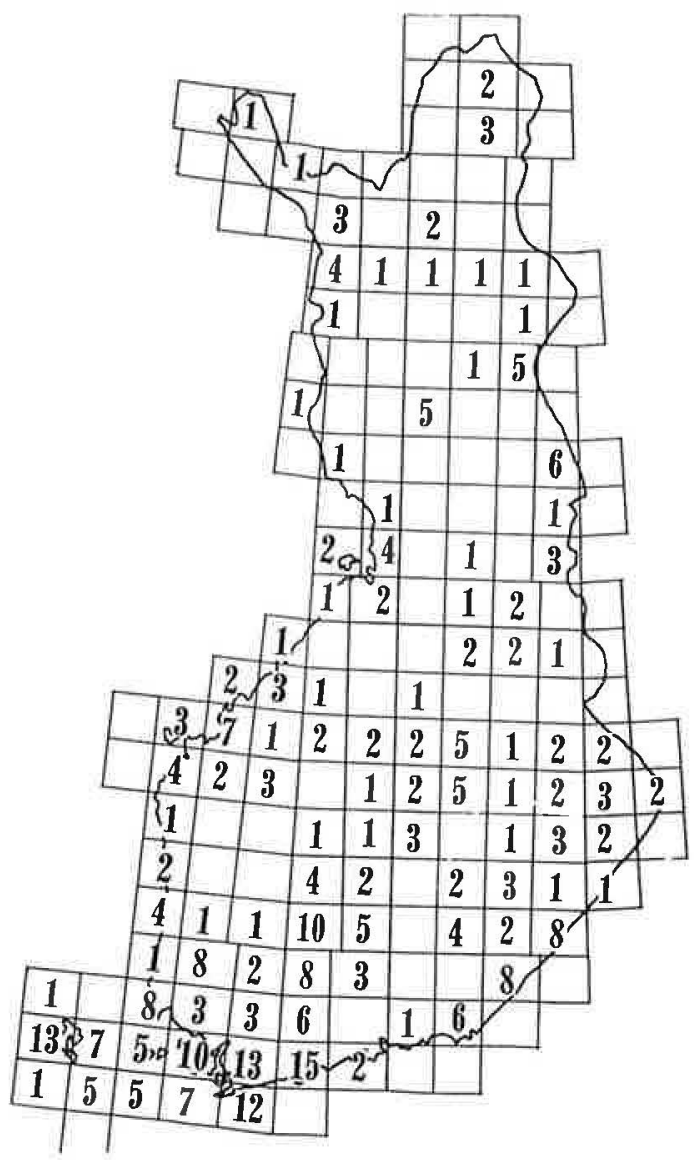

Fig.1. The number of Chlorops species recorded in Finland according to the European UTM grid system.

but it is more thermophilous and xerophilous than Chlorops. Species of Meromyza do not occur on bogs and marshes, as larvae of Meromyza do not develop on Carex, and many species of Chlorops are associated with sedges.

The following groups of species are distinguished according to their distribution in the investigated territory and their general distribution.

1. Species found only in the most southern part of Finland: $C$. centromaculatus, $C$. citrinellus, C. crassipalpis, $C$. distinguendus, $C$. ringens and C. serenus (see corresponding maps in Appendix). The northern limit of the ranges of these species corresponds to the isopleth of effective temperature sums $1200^{\circ}$ (Laaksonen 1979). A similar correlation was recorded for bumblebees ( $\mathrm{Hy}$ menoptera, Apoidae) (Pekkarinen et al. 1981).

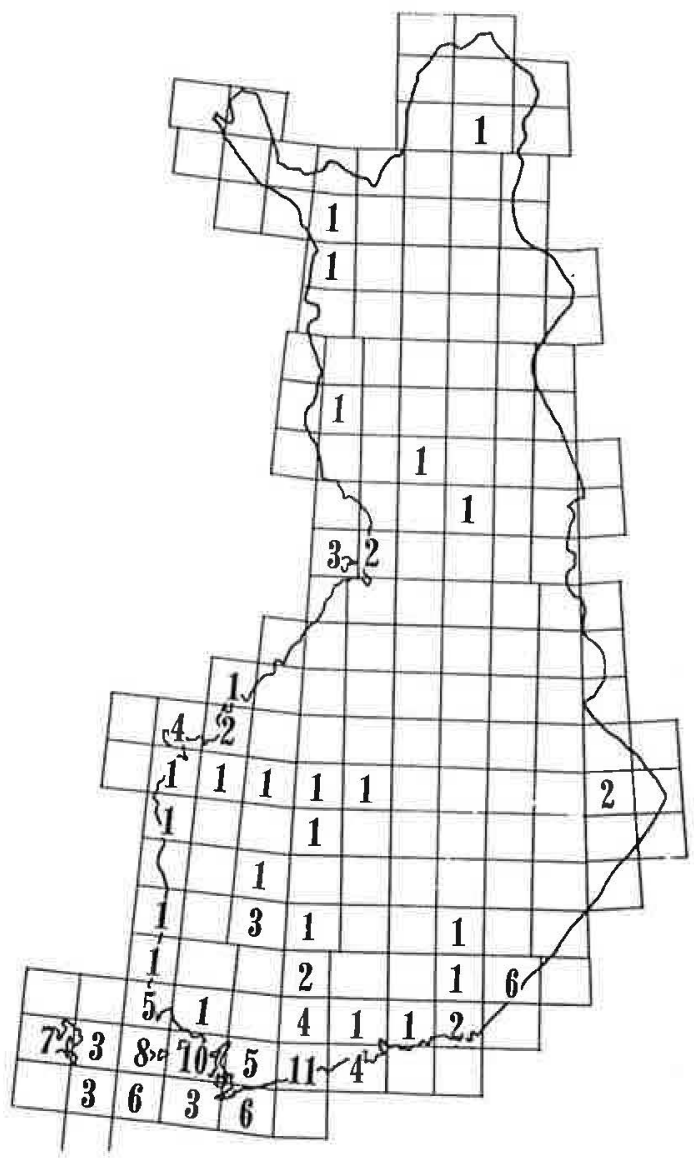

Fig. 2. The number of Meromyza species recorded in Finland according to the European UTM grid system (the map is after Nartshuk, 1992c).

None of these species has been recorded from Karelia and only three (C. citrinellus, $C$. ringens, C. serenus) are known from Estonia and the St. Petersburg region, but exclusively from the southern part of these territories. C. centromaculatus was previously known only from Western Europe (Germany, Austria, Switzerland, Hungary, Northern Italy and Poland). The nearest previously known location of $C$. crassipalpis was the Moscow region. C. distinguendus is known only from Aland and the southwestern coast of Finland. All these species (except C. ringens) are European or European-Mediterranean in distribution.

2. Species found in the southern and central parts of Finland northwards to Pietarsaari or Oulu: C. gracilis, C. obscurellus, C. pumilionis, C. calceatus and $C$. hypostigma. The northern limit of 
the ranges of these species coincides with the isopleth of effective temperature sums $1000^{\circ}$.

All these species occur also in Estonia, the St. Petersburg region and Karelia (in Karelia except for C. obscurellus), but are not found on the Kola Peninsula. These species are known from Europe, the Mediterranean and West Siberia but, except for C. obscurellus, are not found in East Siberia (Yakutia).

3. Species found over nearly the whole of Finland except for the most northern part, northwards to Rovaniemi: C. brevimanus, C. rufinus, C. scalaris, C. troglodytes, $C$. zonulatus, and usually in Karelia, but are not recorded from the Kola Peninsula, except for the southern parts of Murmansk oblast. The northern limit of the ranges of these species nearly coincides with the isopleth of effective temperature sums $800^{\circ}$.

All these species are transpalaearctic polyzonal and boreal or Euro-Asian boreal and known eastwards to East Siberia (Yakutia).

4. Species found all over Finland and further north - on the Kola Peninsula: C. planifrons, C. rossicus, C. rufescens, $C$. scutellaris, C. speciosus, C. varsoviensis, Epichlorops puncticollis and Melanum laterale. The northern limit of the ranges of these species is situated further north than the isopleth of effective temperature sums $700^{\circ}$.

The ranges of these species are Holarctic (Epichlorops puncticollis, Chlorops planifrons), transpalaearctic boreal and polyzonal (C. rufescens, C. varsoviensis, Melanum laterale) or Euro-Asian boreal, eastward to East Siberia (Yakutia). It is noteworthy that most of these species use Carex or other Cyperaceae as their host plants: $C$. planifrons, C. scutellaris, C. varsoviensis, Epichlorops puncticollis, Melanum laterale. The other two species develop on widespread grasses: C. speciosus on Deschampsia caespitosa, and C. rufescens on species of Calamagrostis (except C. epigeios). I have recently intimated that the number of species of Chloropidae developing on Cyperaceae as host-plants is relatively greater in the North, than in the South, Palaearctic (Nartshuk 1992a).

It is significant that some positive correlation exists between the distribution along the meridional and latitudinal gradients. European and EuroMediterranean species have been recorded only from southern Finland. The further north the northern limit of the range of the species, the further east the range of this species extends (see groups $1-4)$. It is very likely that the northern and eastern limits of the range are determined by tolerance for winter temperatures or the length of the winter period.

If we compare the Chloropini fauna of Finland with the known fauna of this tribe in Yakutia (Nartshuk 1993), we can see that many of the species, namely 11, are common (see Table). The index of Czekanowski-Sørensen for these two faunas is 0.53 .

The distribution of C. scutellaris merits detailed consideration here. This is an example of a few species of presumably Siberian origin which occur in Northern Europe. The range of C. scutellaris is rather extensive from North to South in East Siberia (from North Yakutia to Mongolia) and very narrow in Europe: Fennoscandia, Estonia, North-West Russia. The species was not found south of this region (Fig. 3). A similar distribution is known for Opomyza nigriventris Loew (Hackman 1958, Nartshuk 1993).

5. One more group merits consideration, namely species whose northern limit is apparently located in the south of Finland and Karelia. These species are not also found in the northern part of the St. Petersburg region, being known only from the southern part of this region, usually being found in the vicinity of Luga, and from South and West Estonia. They are C. fasciatus Becker, C. figuratus Zetterstedt, $C$. finitimus Becker, $C$. frontosus Meigen, $C$. interruptus Becker, $C$. novakii Strobl, C. pannonicus Strobl, C. riparius Smirnov, $C$. strigulus Fabricius. Some of these species (C. interruptus, C. novakii, C. frontosus, C. strigulus, C. figuratus) have been recorded from Estonia, but are not found in the St. Petersburg region.

Another species ( $C$. pannonicus) is known to occur in Estonia much further north than in the St. Petersburg region. All these species have been recorded in Estonia along the western coast and on the Island of Saaremaa. The northen limits of the ranges of the species in question on the East European plain are oblique, inclining from NorthWest to South-East. Isotherms of the month of January have a similar direction on the East European plain. Moreover, the narrow belt where the frost free period is longer than 150 days is situ- 
Table: List of Chloropini species known from Finland, Estonia, and North-West Russia. Ex = expected species, most of which are rather rare species and difficult to collect. Data on Yakutia (Nartshuk, 1992a) are added for comparison. Only species on the Yakutia list occurring in Finland as well are included. Species occurring in Yakutia with eastern ranges are missing. The figure in parenthesis is the total number of Chloropini species in Yakutia. Abbreviations: ZE = zoogeographical elements, Fin $=$ Finland, Est $=$ Estonia, $\mathrm{SPb}=\mathrm{St}$. Petersburg region, $\mathrm{Kr}=$ Karelia, $\mathrm{Lr}=$ the Kola Peninsula, $\mathrm{Ya}=$ Yakutia. Zoogeographical elements: $\mathrm{E}=$ European, $\mathrm{EAb}=$ Euro-asian boreal, $\mathrm{EAp}=$ Euro-asian polyzonal, $\mathrm{EAt}=$ Euro-asian temperate, $\mathrm{EC}=$ Euro-caucasian, $\mathrm{AM}=$ Euro-mediterranean, EK $=$ Euro-kazakhstanian, $\mathrm{H}=$ Holarctic, NEAb $=$ North-euro-asian boreal, $\mathrm{TPb}=$ Transpalaearctic boreal, TPp $=$ Transpalaearctic polyzonal, TPt $=$ Transpalaearctic temperate .

\begin{tabular}{llllllllllllllllll}
\hline Species & ZE & Fin & Est & SPb & $\mathrm{Kr}$ & $\mathrm{Lr}$ & $\mathrm{Ya}$
\end{tabular}

Chlorops

\begin{tabular}{|c|c|c|c|c|c|c|}
\hline anthracophagoideus Strobl & EC & $e x$ & ex & + & + & - \\
\hline brevimanus Loew & Tpp & + & + & + & + & + \\
\hline calceatus Meigen & $\mathrm{Eab}$ & + & + & + & + & ex \\
\hline centromaculatus Duda & $E$ & + & ex & - & - & - \\
\hline citrinellus Zetterstedt & $E$ & + & + & + & ex & - \\
\hline crassipalpis Smirnov & EK & + & ex & ex & - & - \\
\hline distinguendus Frey & $E$ & + & - & - & - & - \\
\hline fasciatus Meigen & Eat & - & + & + & - & - \\
\hline figupatus Zetterstedt & Eab & ex & + & ex & ex & - \\
\hline finitimus Becker & EM & - & ex & + & - & - \\
\hline frontosus Meigen & E & - & + & - & - & - \\
\hline geminatus Meigen & Eat & ex & + & + & + & - \\
\hline gracilis Meigen & Eat & + & + & + & + & - \\
\hline hypostigma Meigen & EC & + & + & + & + & - \\
\hline interruptus Meigen & EM & - & + & - & - & - \\
\hline laetus Meigen & EC & ex & + & + & + & - \\
\hline nigripalpis Duda & $\mathrm{E}$ & ex & ex & ex & + & - \\
\hline novakii Strobl & Eat & - & + & - & - & - \\
\hline obscurellus Zetterstedt & Eab & + & + & + & ex & ex \\
\hline palpatus Smirnov & $E$ & - & $e x$ & + & - & - \\
\hline pannonicus Strobl & Tpt & - & + & + & - & - \\
\hline planifrons Loew & $\dot{H}$ & + & + & + & + & + \\
\hline pumilionis Bjerkander & Eat & + & + & + & + & - \\
\hline ringens Loew & Eat & + & + & + & ex & - \\
\hline riparius Smirnov & Eat & - & ex & + & - & - \\
\hline rossicus Smirnov & $E$ & + & + & + & + & ex \\
\hline rufescens Oldenberg & Tpb & + & + & + & + & + \\
\hline rifinus Zetterstedt & Tpp & + & + & ex & + & - \\
\hline scalaris Meigen & Eap & + & + & + & + & - \\
\hline scutellaris Zetterstedt & NEAb & + & + & + & ex & + \\
\hline serenus Loew & EM & + & + & + & - & - \\
\hline speciosus Meigen & Eab & + & + & + & + & + \\
\hline strigulus Fabricius & Eat & - & + & - & - & - \\
\hline troglodytes Zetterstedt & Eab & + & + & + & + & + \\
\hline varsoviensis Becker & Tpp & + & + & + & + & + \\
\hline zernyi Duda & Eab & ex & ex & + & + & ex \\
\hline zonulatus Wahlgren & $\mathrm{Tpb}$ & + & $e x$ & + & + & - \\
\hline
\end{tabular}

Epichlorops

puncticollis Zetterstedt

$\mathrm{H}$

Melanum

laterale Haliday 


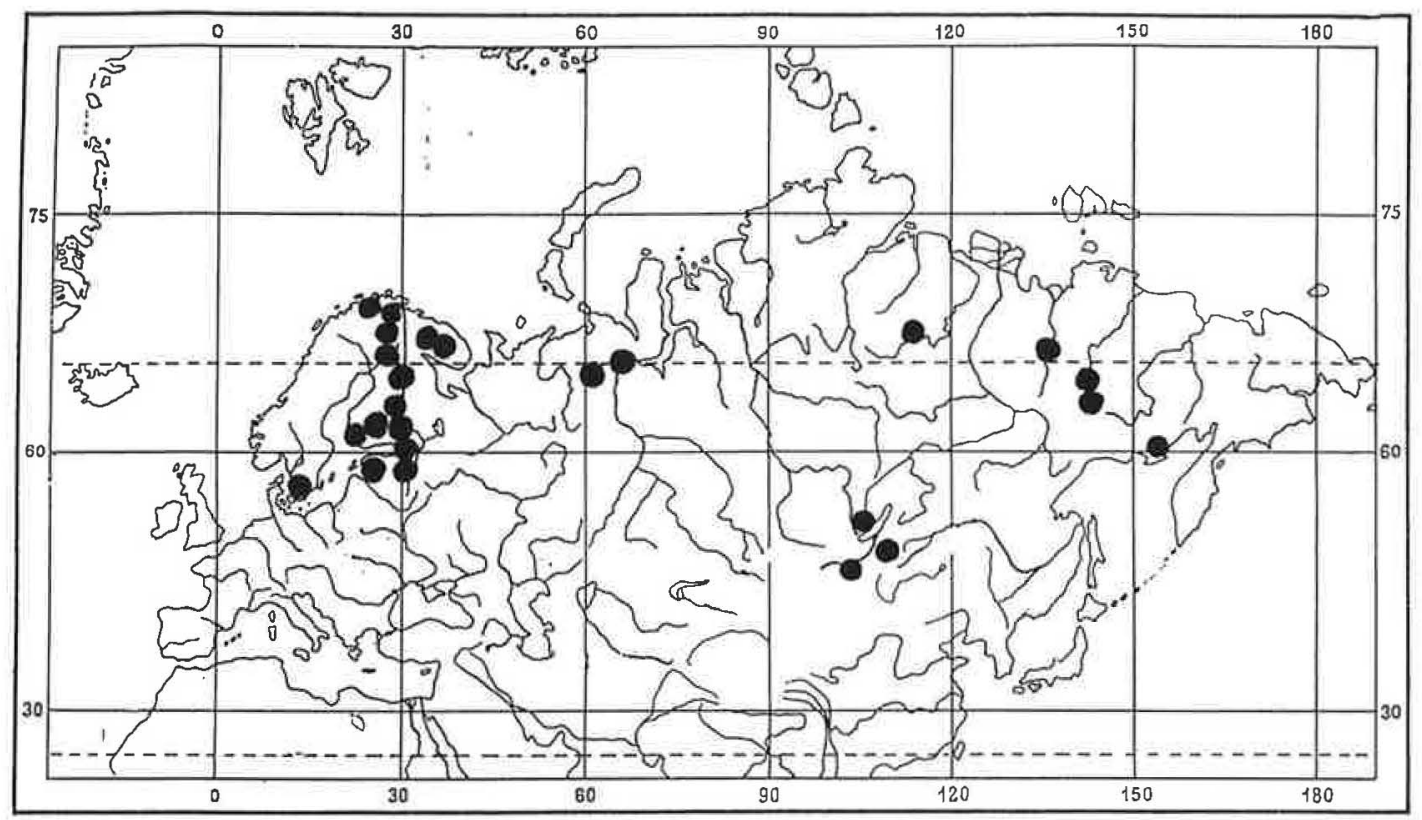

Fig. 3. The distribution of Chlorops scutellaris.

ated along the western coast of Estonia. The frost free period in the territory situated eastward of this belt is only 135 days (Gerasimov et al. 1964). This suggests that winter environmental conditions are apparently responsible for the northern limits of the ranges of Chloropidae, especially species hibernating as larvae. Kovalev (1978) also pointed out that the Tachidromiinae (Empididae) fauna in western Estonia is enriched by southern elements, very likely relicts of a warm subatlantic period, with a comparison of the faunas of southern Finland and the St. Petersburg region.

\section{Key to species of the tribe Chloropini}

The genus Parectecephala which is expected in the territory in question is included in the key. Most species can be rather well identified by morphological characters without an investigation of the male genitalia. The colour of the body (arista, first flagellomere, frontal triangle, spot on katepisternum, etc.) is also rather informative in spite of its variability. Dark coloured specimens from northern Finland, Karelia and the Kola Peninsula are more difficult to identify.

Drawings of male genitalia are presented only for some pairs of similair species and investigation of the male genitalia is necessary only in questionable cases. The sclerites of the abdomen, including male genitalia, in species of the tribe Chloropini are weakly sclerotized. Consequently, it is better to stain the male genitalia to distinguish all the details. Fairly good results were received with a slightly modified version of Wilkey's method (1962). I use the following procedures for dry specimens. The cut tip of the abdomen is placed in $10 \% \mathrm{KOH}$ solution ( $30 \mathrm{~min}-1$ hour). Then it is transferred to Essig Acids Fluid with double stains: lignin pink and acid fuchsin (1-2 and more hours without heating), and then placed in $96 \%$ alcohol. The male genitalia are then examined and kept in glycerol.

Chlorops Meigen, 1830.

Type-species Musca pumilionis Bjerkander, 1778 (des. ICZN, 1955, op. 348:423).

Body yellow or brownish yellow, 1.5-6 mm long (Fig. 4). Wing venation as in Fig. 5. Eyes moderately large, rounded to broad oval with short sparse hairs. Gena usually broad, rarely narrow (Fig. 7-9). Frons with numerous hairs. Frontal triangle large, reaching middle of frons or to front of frons, often as narrow line, smooth or with 
ridges along side margins, without hairs or punctures. Colour of frontal triangle yellow to black, usually yellow with leaf like black spot and sometimes with yellow window spots. Face usually retreating. Palpi short or long and thick, usually yellow, rarely entirely black or only with black tip. Antennae yellow to black.

The first flagellomere as long as broad or slightly longer than broad. Arista black or white with short pubescence. Scutum with 3-5 black or reddish stripes, which are rarely fused (Figs 11-14). Scutellum concave, yellow, rarely brownish. Legs slender without tibial organ. Male fore tarsi sometimes modified with short fore metatarsus and asymmetrical claws. In male genitalia middle lobe of surstyli with hooklike apex, pregonites situated laterally of postgonites (Figs 15-27).

The genus is divided into 3 subgenera: Chlorops s. str. (most of the species included in the key), Sclerophallus Beschovski (C. brevimanus, C. varsoviensis) and Asianochlorops Kanmiya (C. distinguendus).

Parectecephala Becker, 1910.

Type-species Oscinis longicornis Fallén (des. Duda, 1933).

Flies are similar to Chlorops, but the first flagellomare is longer than broad and arista white and thick pubescent. Male genitalia is Chlorops type.

\section{Melanum Becker, 1910.}

Type-species Chlorops lateralis Haliday, 1933 (orig. des.).

Flies are similair to Chlorops, but gena projecting to front, vibrissal corner is acute (Fig. 10). Scutum entirely black and pollinose. In male genitalia postgonites look like postgonites of Chlorops, but pregonites indistinct. Epandrium is flat below and with carina along lower margin.

\section{Epichlorops Becker, 1910}

Type-species Oscinis puncticollis Zetterstedt, 1848 (orig. des.).

Flies are similar to Chlorops, but scutum entirely black and scarcely punctured, frontal triangle large, smooth, reaching front of frons in a rather broad tip. Male genitalia is Chlorops type.

1. The first antennal flagellomere nearly 2 times longer than broad. Scutum yellow with 5 pollinose dull black stripes, lateral stripes with velvet black spot on front part

Paractecephala longicornis

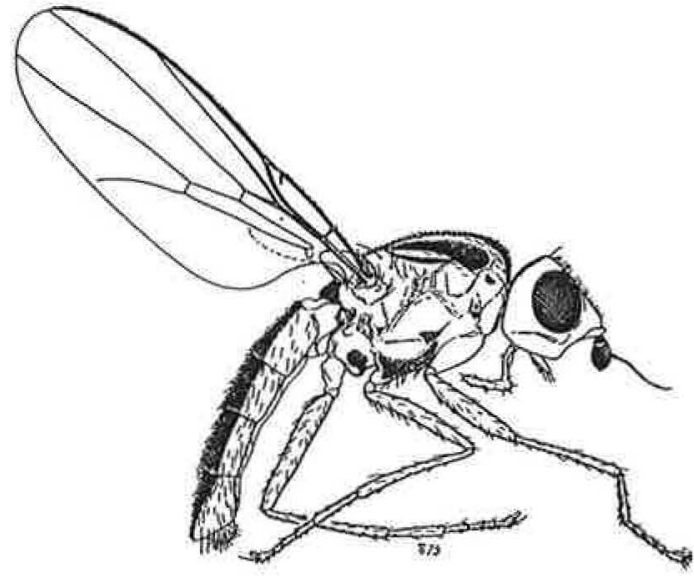

Fig. 4. Chlorops sp. Lateral view.

- The first antennal flagellomere as long as broad or nearly so. Scutum black or yellow with black or red stripes, without velvet black spot (Figs 11-14) ................ 2

2. Gena very narrow, not broader than fore tibia. The first flagellomere distinctly broader than basal segments of antennae. Frontal triangle with nearly parallel sides basally (Figs, 6 and 7) ........ Chlorops distinguendus

- Gena more broad, nearly as broad as the first flagellomare or broader (Fig. 8 and 9)

3. Scutum entirely black, postpronotum black or yellow with black spots. Scutellum sometimes black or darkened

4

- Scutum yellow with 3-5 black or reddish stripes. Postpronotum usually yellow, very rarely with black spot. Scutellum usually yellow, very rarely with dark middle (Fig. 11-14)

4. Basal segments of antennae yellow or only slightly darkened. Gena broader than first flagellomare, sometimes with black hairs. Yellow parts of body usually darkened ... Chlorops speciosus, and Chlorops rufescens, dark forms. Investigations of male genitalia are needed to distinguish dark forms of these species: see Figs 22-25.

- Antennae including basal segments entirely black. Gena at most as broad as first flagellomare. Yellow parts of body sharply contrasting with black parts ............. 5

5. Vibrissal corner projecting and acute (Fig. 10). Scutum smooth, dull thinly pollinose ....... Melanum laterale

- Vibrissal corner obtuse, not projecting (Figs. 8 and 9). Scutum shining and smooth or scarcely punctured ...

6. Frontal triangle extending to front of frons by broad apex. Scutum scarcely punctured

Epichlorops puncticollis

- Frontal triangle with acute apex and not extending to front of frons. Scutum smooth and polished. Male genitalia Figs. 15 and 16 ............... Chlorops scutellaris

7. Palpi long and thick and sometimes black on tip ... 8

- Palpi not long, yellow, sometimes black on tip or entirely black, in last case arista white 12 


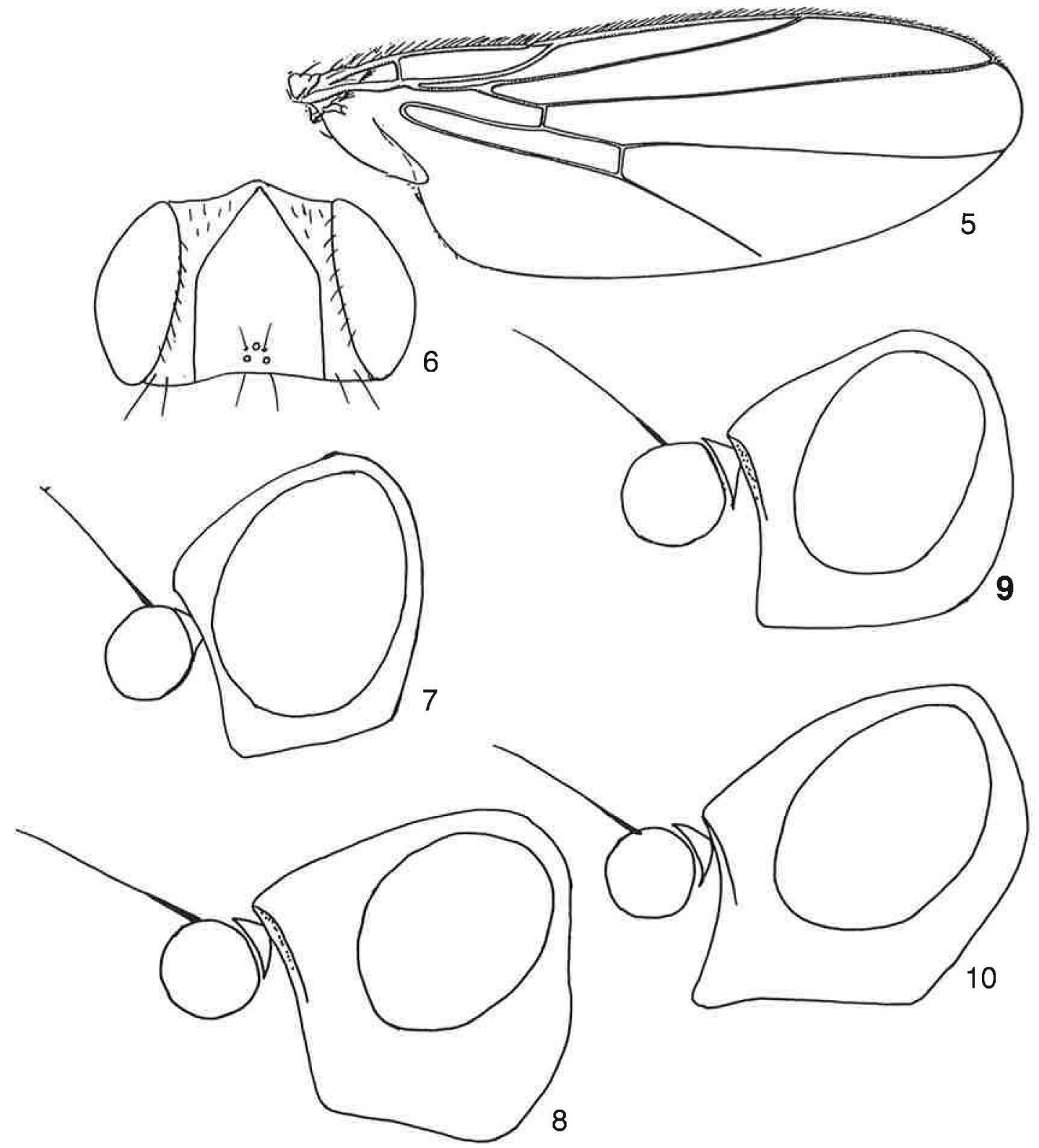

Figs 5-10. -5 : Venation of Chlorops wing; -6 : frons of $C$. distinguendus; -7 : head of $C$. distinguendus, lateral view; -8 : head of $C$. serenus, lateral view; -9 : head of $C$. anthracophagoideus, lateral view; -10 : head of Melanum laterale, lateral view.

8. Spot on katepisternum shining black.

11

- Spot on katepisternum yellow, reddish yellow, at most brownish on upper part

9. Gena narrower, no broader than the first flagellomere. Frontal triangle with more or less distinct groove in apical part. Palpi, especially in male, darkened at tip Chlorops palpatus

- Gena broader than the first flagellomere. Frontal triangle without groove in apical part. Palpi yellow or darkened only in female ..................................................... 10

10. Frontal triangle yellow with small dark spot only on ocellar tubercle and around it. Stripes on scutum shining. Abdomen predominantly yellow. Palpi yellow in both sexes, palpi of female longer and thicker than in C. ringens ................................. Chlorops centromaculatus - Frontal triangle predominantly black, yellow only along 
Figs 11-14. - 11: Scutum of C. pannonicus; -12 : scutum of $C$. finitimus; 13: scutum of $C$. rossicus; - 14: scutum of $C$. rufescens.
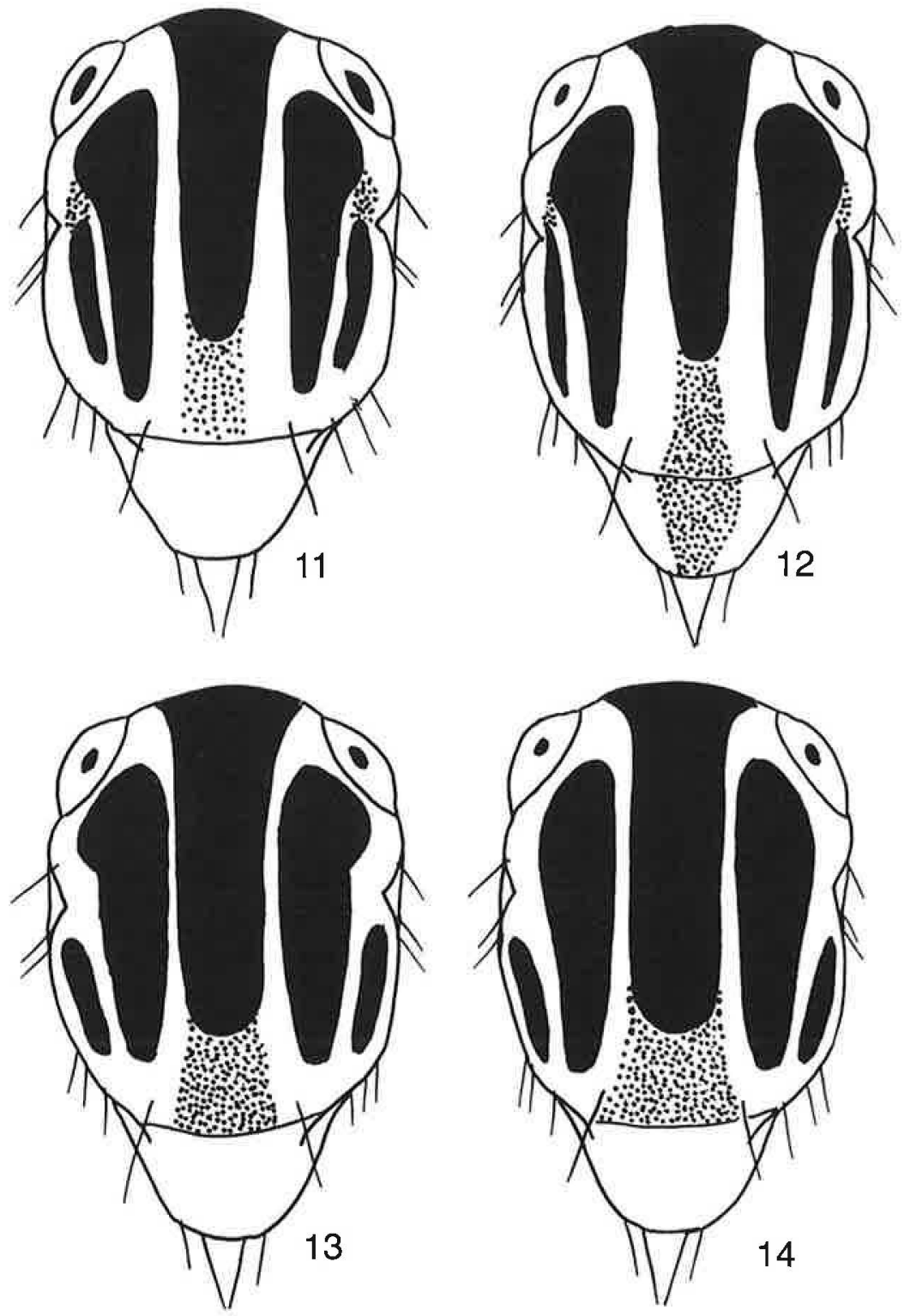

Iateral sides and sometimes with yellow window spots. Stripes on scutum subshining thinly pollinose. Abdomen with black bands, sometimes connected by median line. Palpi in female darkened at tip

Chlorops ringens

11. Palpi long thick and distinctly extending from oral cavity, blackish at tip. Abdomen yellow without black bands, only with two black spots at base. The first flagellomere black. Stripes on scutum dull grey pollinose. Female cerci narrower Chlorops crassipalpis

- Palpi shorter and not thick, rarely blackish at tip. Abdomen yellow with distinct narrow black bands on fore margin of the 2-5 tergites and sometimes with black median line. The first flagellomere from yellow to almost black. Stipes on scutum shining or subshining with only thinly polinose

Chlorops scalaris

12. Stripes on scutum reddish yellow. Frontal triangle shining yellow with two small black spots, one on ocellar tubercle and another on apex of frontal triangle. Antennae yellow Chlorops rufinus

- Stripes on scutum black shining or thick grey pollinose and dull. If stripes partly reddish brown, frontal triangle large, extending to front of frons, shining yellow without two black spots

13

13. Gena narrower, subequal to the first flagellomere or narrower 14 

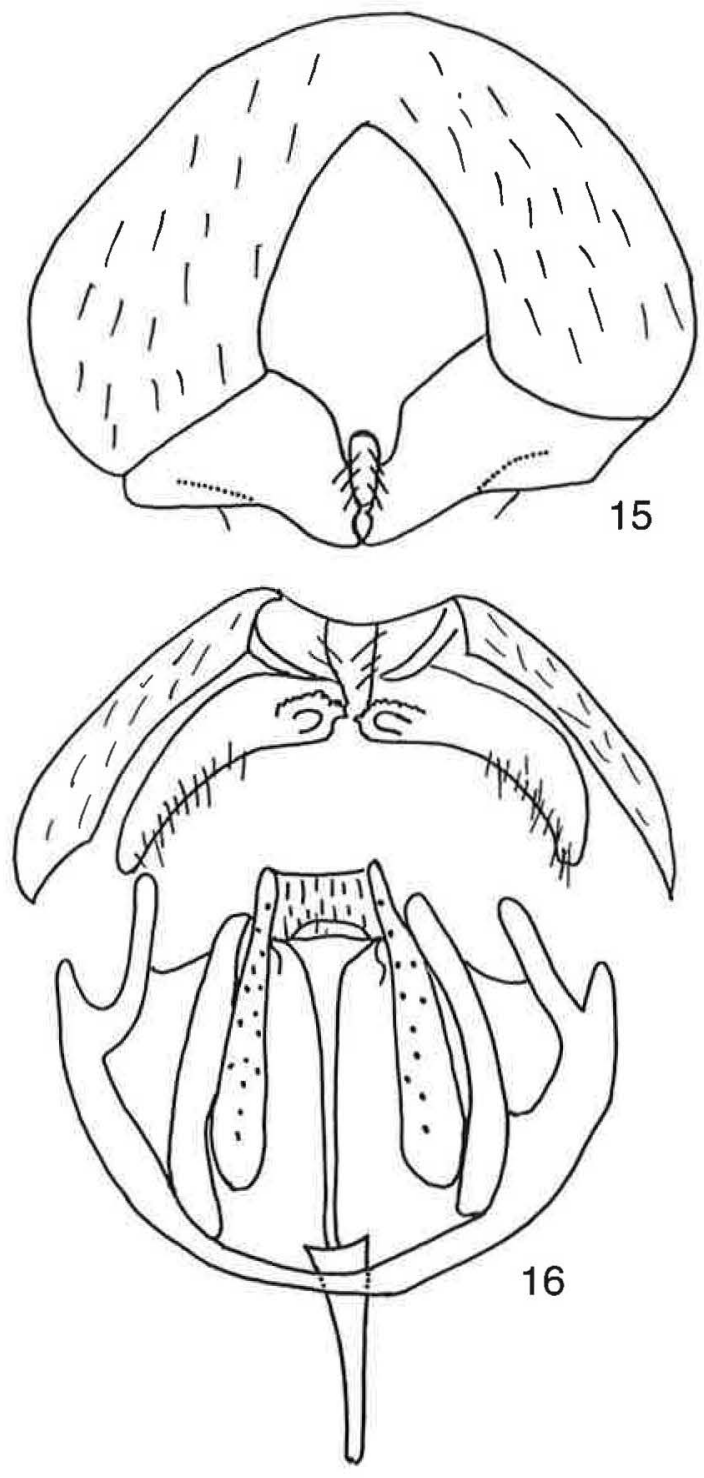

- Gena broader, equal to the first flagellomere or usually markedly broader

18

14. Arista white, sometimes weakly thickened. Frontal triangle shining yellow with black ocellar and apical spots, connected by dark line. Antennae and palpi black .... Chlorops anthracophagoideus

- Arista black or grey, not thickened

15. Frontal triangle yellow with one black spot on ocellar tubercle and another apical rhomboid black spot. Arista grey Chlorops citrinellus

- Frontal triangle entirely black or yellow with more or less large black spot. Arista black 16

16. Male fore metatarsus short, no more than 3 times longer than thick, fore claws asymmetrical. Stripes on scutum dull thickly pollinose

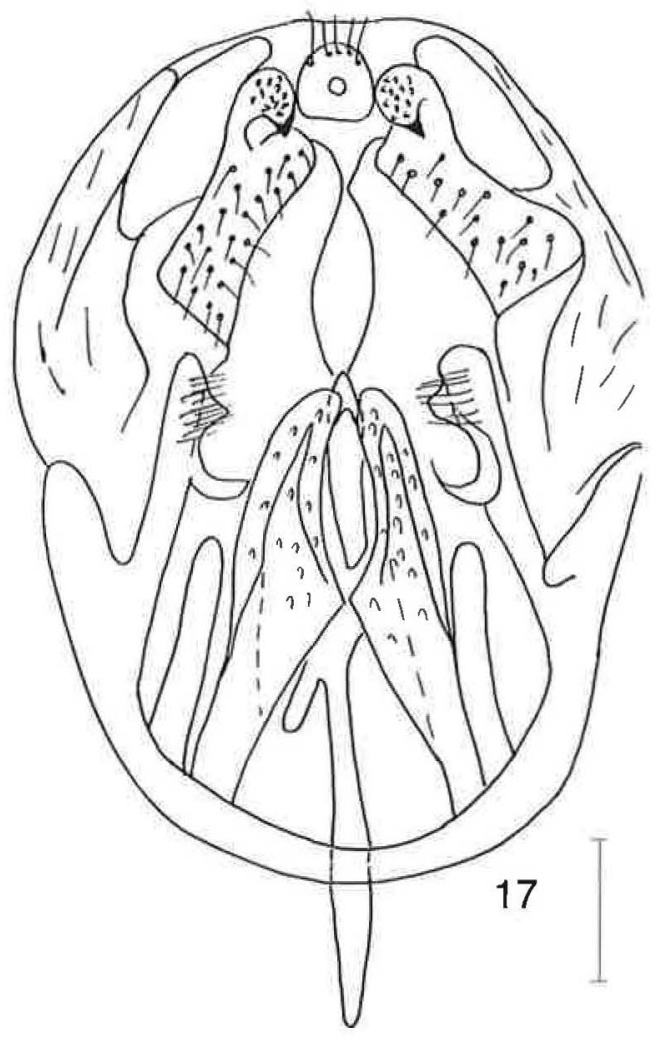

Figs. 15-17. -15 and 16: Male genitalia of C. scutellaris; - 17: male genitalia of C.pumilionis. - Scale bars $0.1 \mathrm{~mm}$.

- Male fore metararsus long, 5 times longer than thick, fore claws symmetrical. Stripes on scutum shining. Abdomen predominantly yellow

Chlorops hypostigma

17. Anepisternum with some small hairs, which are usually black in female and white in male. Hairs on scutum partly yellow. Frontal triangle black in the middle, lateral sides and hinter corners being yellow. Antennae from black to yellow. Palpi black or yellow. Abdomen reddish brown in female, yellow or darkened dorsally in male

Chlorops varsoviensis

- Anepisternum without hairs. Hairs on scutum black. Frontal triangle entirely black. Palpi yellow. Basal antennal segment yellow. The first flagellomere rather large, black 

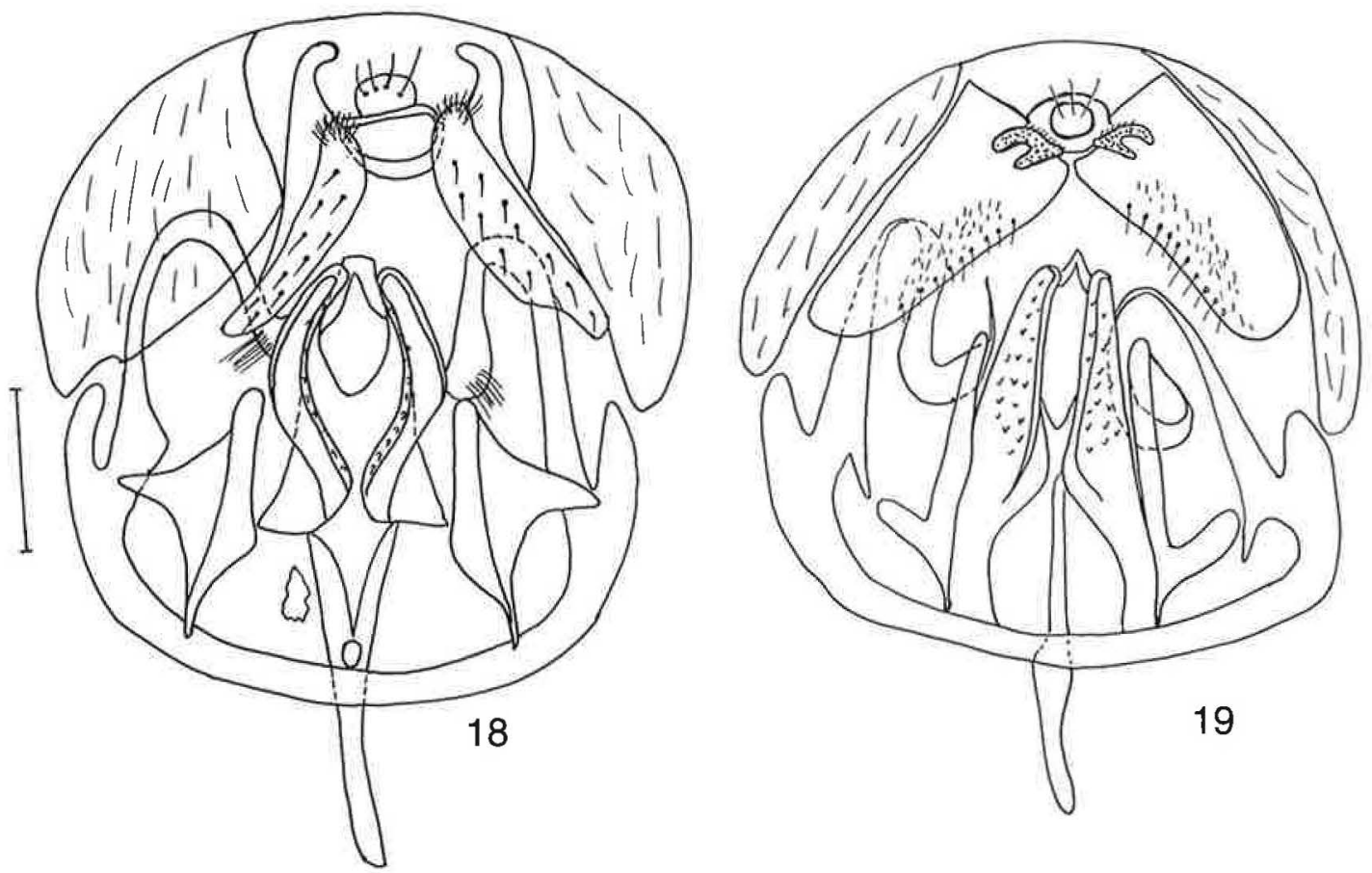

Figs. 18 and 19. - 18: Male genitalia of C.figuratus; - 19: male genitalia of C. novakii. - Scale bars $0.1 \mathrm{~mm}$.

18. Stripes on scutum black dull thick pollinose and therefore grey. Spot on katepisternum grey pollinose, shining black or reddish yellow

18

- Stripes on scutum black shining without pollinose or subshining if only thin pollinose. Spot on katepisternum black shining or reddish yellow without pollinose ....

36

19. The first flagellomere longer haired than arista. Frontal triangle from entirely black to mostly yellow. Anepisternum with some black or white hairs

Chlorops fasciatus

- The first flagellomere with short hairs. Anepisternum with black hairs or without hairs

20

20. Lateral stripes on scutum enlarged laterally and connected in front with marginal stripes (Fig. 11) ..... 21

- Lateral and marginal stripes well separated .......... 22

21. The first flagellomere slightly longer than broad, usually yellow, at most slightly darkened on upper side. Palpi and scutellum yellow ............. Chlorops pannonicus

- The first flagellomere as long as broad, black. Palpi and middle of scutellum black or brownish (Fig. 12)

Chlorops finitimus

22. Spot on katepisternum black and dull thick pollinose, therefore grey

23

- Spot on katepisternum shining or subshining black or reddish yellow

23. Arista white weakly thickened. Frontal triangle wrinkled. Scutellum darkened. Palpi black

24

- Arista black. Frontal triangle black or partly yellow smooth, not wrinkled. Palpi yellow
24. Antennae predominantly yellow, at most the first flagellomere slightly darkened on upper side. Frontal triangle dull, greyish brown, wrinkled along lateral sides ...... Chlorops strigulus

- Antennae black except white arista. Frontal triangle shining brown, wrinkled on all surface

Chlorops frontosus

25. Anepisternum with some black hairs. Basal segments of antennae yellow, the first flagellomere yellow with darkened upper side. Fore metatarsus and tip of fore tibia yellow. Frontal triangle mostly yellow without median groove before fore ocellus ....... Chlorops laetus

- Anepisternum bare, without hairs. Basal segments of antennae black or strongly darkened, the first flagellomere black, very rare dark yellow at base on inner side. Fore metatarsus and tip of fore tibia blackish. Frontal triangle from entirely black to almost yellow with black median line and black ocellar triangle, before fore ocelIus with groove which transforms into low ridge in apical part triangle. Male genitalia Fig. 17

Chlorops pumilionis

26. Palpi black or darkened in apical part ................. 27

- Palpi yellow ............................................................ 28

27. Arista white. Spot on katepisternum reddish yellow. Head longer than deep in side view

Chlorops zernyi

-- Arista black. Spot on katepisternum black Chlorops nigripalpis

28. The first flagellomere black or at most slightly brownish at base on inner side 

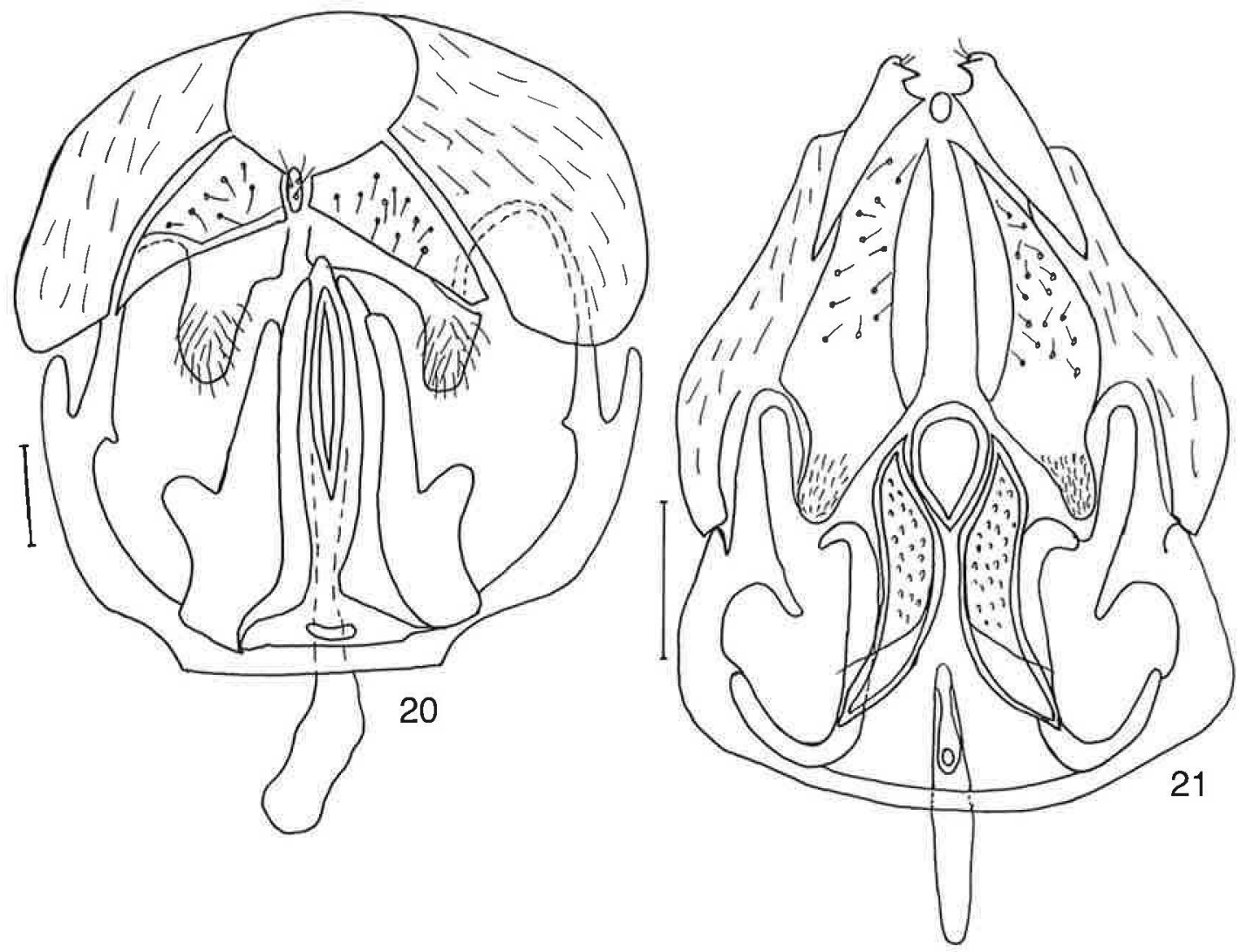

Figs. 20 and 21. - 20: Male genitalia of C.zonulatus; -21 : male genitalia of $C$. geminatus. - Scale bars $0.1 \mathrm{~mm}$.

- The first flagellomere yellow or at most darkened only on upper and outer sides 32

29. Frontal triangle large, extending to anterior margin of frons or $0.75-0.9$ length of frons without distinct linear part, sometimes wrinkled in apical part. If short linear part present, arista whitish or yellowish in apical part. Spot on katepisternum black or reddish yellow .... 30

- Frontal triangle extending 0.5-0.7 length of frons and continues as a line to anterior margin of frons, not wrinkled, mostly yellow, black only on middle or with yellow window spots. Gena very broad 31

30. Arista black. Frontal triangle black without yellow parts, polished, wrinkled in apical part. Stripes on scutum wide. Scutellum sometimes slightly darkened. Spot on katepisternum black. Abdomen blackish dorsally. Female cerci short and broad ...... Chlorops obscurellus

- Arista yellowish or whitish in apical part. Frontal triangle from almost black to yellow with two black spots: on ocellar tubercle and at apical part. Frontal triangle not wrinkled and sometimes with medial groove in apical part. Stripes on scutum narrow, scutellum yellow. Spot on katepisternum black or reddish yellow. Abdomen yellow with dark bands on anterior part of tergites and dark median line. Female cerci long and narrow, divergent in dry specimens ...... Chlorops planifrons 31. Spot on katepisternum reddish yellow. Black spot on frontal triangle small usually with yellow window spots near ocelli Chlorops serenus

- Spot on katepisternum black subshining. Median part of frontal triangle black without yellow window spots, but lateral sides and hind corners broad yellow

Chlorops riparius

32. Frontal triangle large smooth shining extending to front of frons, without distinct linear part. Stripes on scutum thickly pollinose grey or rarely partly reddish brown ..

Chlorops interruptus

- Frontal triangle with more or less expressed linear part, often wrinkled or swollen along lateral side, or with groove before ocellus, often with whitish spots in front of ocellar tubercle 33

33. Frontal triangle smooth, medial part usually black ... .. 34

- Frontal triangle wrinkled at apex along lateral sides, or swollen along lateral sides, medial part whitish ... 35

34. The first flagellomere entirely yellow. Anepisternum often with some yellow hairs. Male genitalia as in Fig. 18

Chlorops figuratus

- The first flagellomere yellow, blackish on upper and 

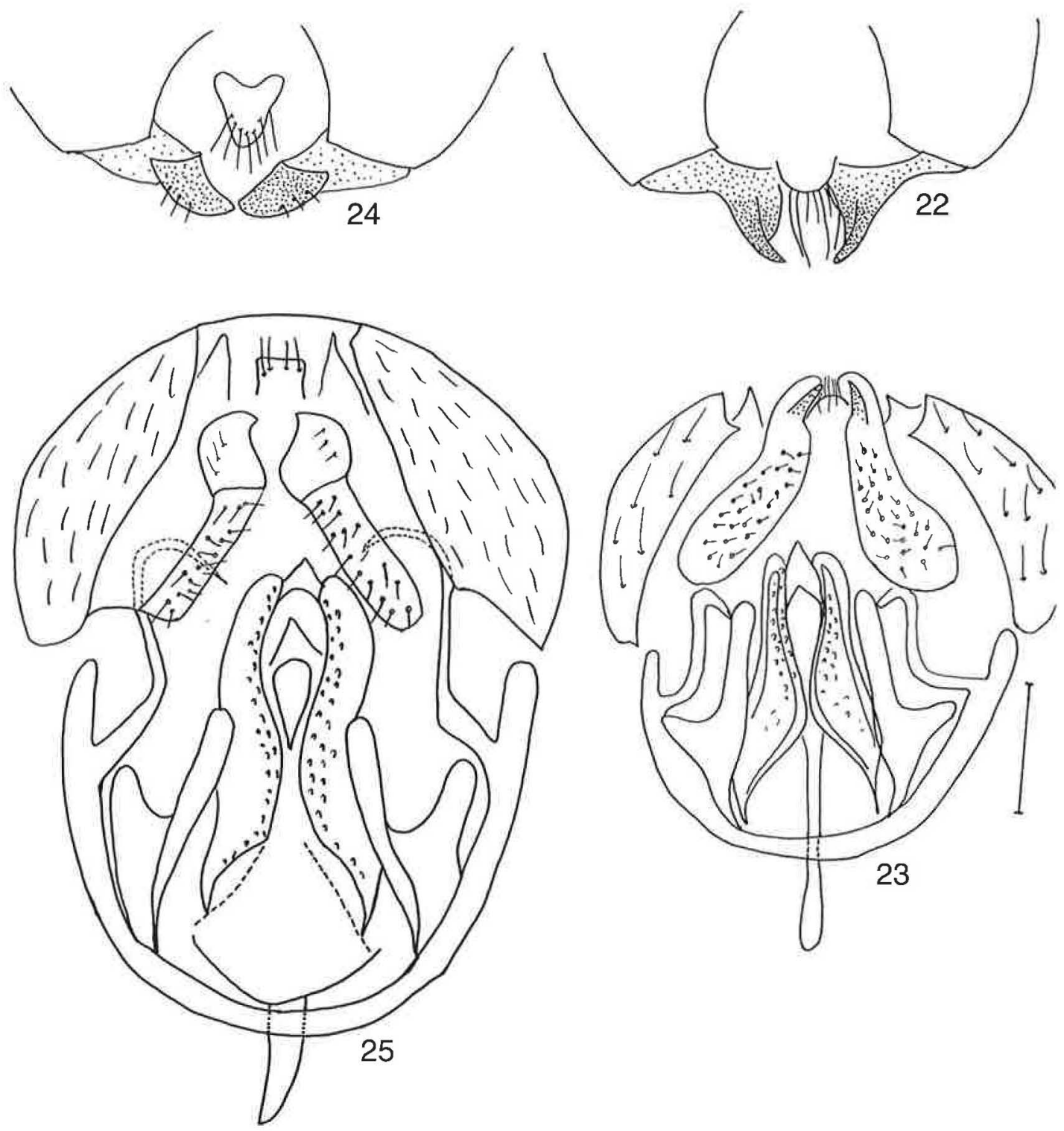

Figs. 22-25. -22 and 23: Male genitalia of C. rufescens; -24 and 25: male genitalia of C. speciosus. - Scale bars $0.1 \mathrm{~mm}$.

outer sides. Anepisternum without hairs. Male genitalia Fig. 19 Chlorops novakii

35. Frontal triangle dull short, extends 0.5 length of frons and continues to anterior margin of front as a line. Lateral side of frontal triangle swollen. Black spots are situated on ocellar tubercle, on lateral sides and on apex. Palpi short and thick. Male genitalia as Fig. 20

\section{Chlorops zonulatus}

- Frontal triangle shining, longer, linear part not so distinct. Median part of frontal triangle whitish. Male genitalia as in Fig. 21
Chlorops geminatus
36. Wings weakly darkened greyish or brownish ...... 37

- Wings uncoloured ...................................................... 38

37. First flagellomere and spot on katepisternum black. Frontal triangle predominantly black. Outside margin of lateral stripes on scutum with triangular projection behind postprotonum (Fig. 13) .... Chlorops rossicus

- First flagellomere yellow or darkened on upper and outer sides. Spot on katepisternum yellow or brownish on upper part. Black spot on frontal triangle not occupying apical part, lateral sides and hind corners of triangle. Outside margin of lateral stripes on scutum more 

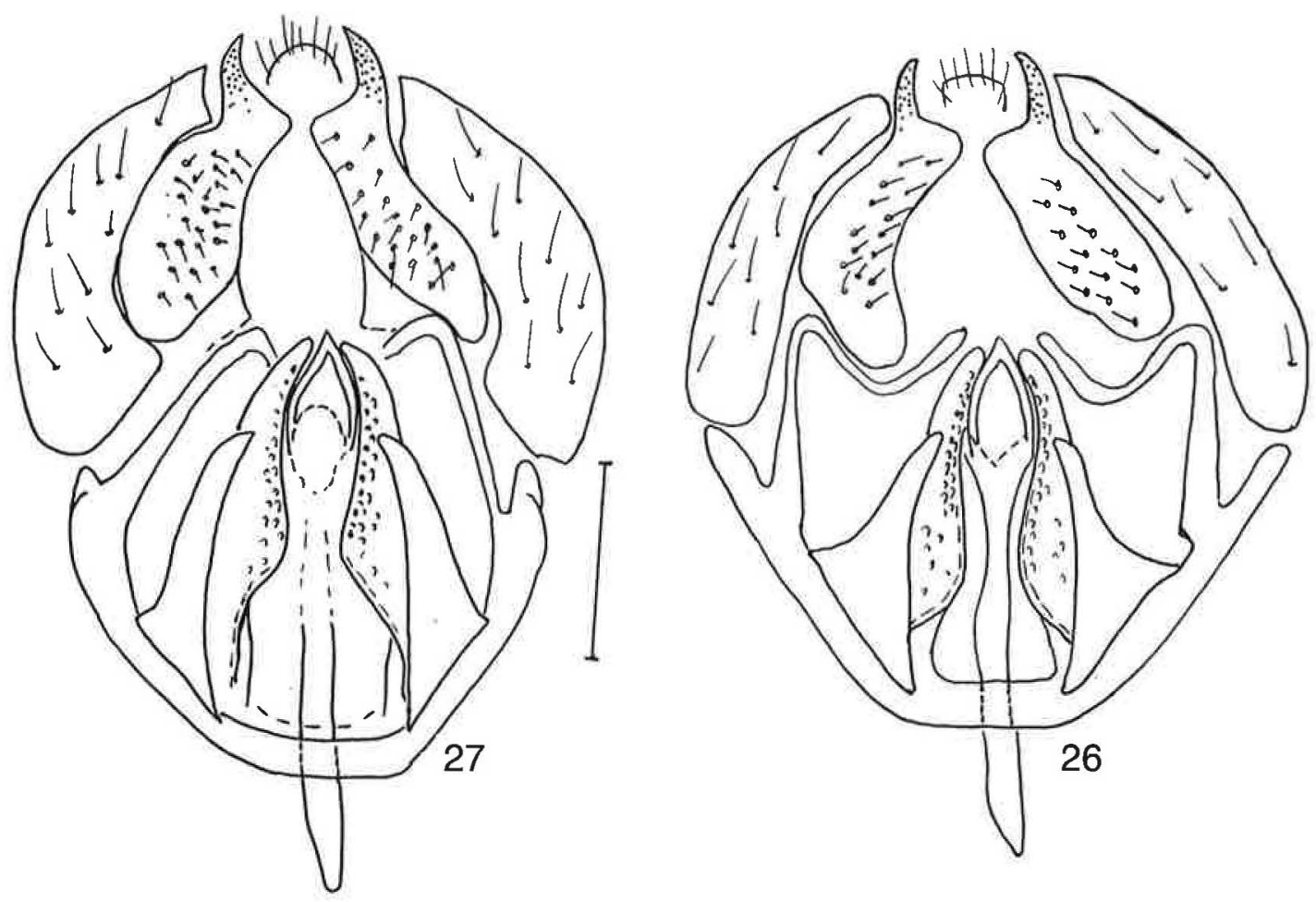

Figs. 26 and 27. -26 : Male genitalia of $C$. troglodytes; -27 : male genitalia of $C$. calceatus. - Scale bars $0.1 \mathrm{~mm}$.

or less even, without projection (Fig. 14). Male genitalia Figs. 22, 23 Chlorops rufescens

38. Stripes on scutum shining without pollinose. Frontal triangle entirely black or with dark yellow window spots laterally from central line, but lateral sides and hind corners always black. Gena with black hairs. Body larger, 3.5-6.0 mm long. Male genitalia Figs. 24, 25

Chlorops speciosus

- Stripes on scutum subshining with thin pollinose. Frontal triangle black or yellow along lateral sides and on hind comers. Gena without black hairs. Body smaller 3.0-3.5 $\mathrm{mm}$ long

39

39. Abdomen brown or black dorsally. Basal segments of antennae brownish. Frontal triangle entirely black or narrow yellow along lateral sides and on hind corners. Black stripes on scutum wider. Female cerci triangular if adjoined (dorsal view). Male genitalia as in Fig. 26 Chlorops troglodytes

- Abdomen dorsally yellow with black bands. Frontal triangle wide yellow along lateral sides and on hind corners. Basal segments of antennae yellow. Black stripes on scutum narrower. Female cerci truncate if adjoined (dorsal view). Male genitalia as in Fig. 27 .. Chlorops calceatus

\section{List of species found in Finland, Ka- relia $(K r)$ and the Kola Peninsula (= Mur- mansk oblast, $L r$ ).}

The abbreviations of the biological provinces in Finland are used according to the series Fauna entomologica scandinavica. There is no Finnish Chloropini material reared from plants available, but hostplants are mentioned for some species on observations on other parts of the Palaearctic.

\section{Chlorops anthracophagoideus Strobl, 1900.}

Russia. Kr: Gizhino (Platonoff) 10"; Kolatselga, 18.VI.1943 (Tiensuu) $10^{7}$. Total 2 specimens.

The species is easily distinguished by thickened white arista with yellow base; short black palpi and large yellow frontal triangle, with ocel- 
lar tubercle and apex black. Rare species. Only four specimens were found during many years of collecting in the St. Petersburg region. Not found in Finland, the nearest localities - Russia, IK: Polarny and Sweden: Eriksberg (according to specimens in ZIN and ZMH). The species is expected to be found in Finland.

Euro-caucasian, known from Sweden and Belgium to Bulgaria and the Transcaucasus.

\section{Chlorops brevimanus Loew, 1866.}

Finland. $A l$ : Eckerä, Hammarland. $A b$ : Dragsfjärd, Kaarina Kuusisto, Nauvo, Sammatti, Sandskär, Tvärminne, Uusikaupunki. N: Espoo, Helsinki, Kirkkonummi. Ta: Sysmä, Tampere, Teisko. Sa: Joutseno, Imatra. $T b$ : Jyväskylä. $O b$ : Rovaniemi Pisavaara naturpark. Total $150^{\circ} 0^{7}, 15$ фo.

Russia. Kr: Sortavala, Valaam, river Kuzhma, Salmi. Total 2 Ơం $^{7}, 2$ 우. Lr: Kuolajärvi, 3 ơ $0^{\prime \prime}, 5$ 우요.

Adults in June-August on wet meadows. Larvae develop in stems of Phalaroides arundinaceae. The species is characterized by the large black first flagellomere of antennae, entirely black frontal triangle, usually with small median ridge in apical part. The male fore metatarsi are short and claws of fore legs are asymmertrical. Palpi rather short and slightly thickened.

Transpalaerctic polyzonal species; known from Finland to Spain and Bulgaria and from Britain to Japan.

\section{Chlorops calceatus Meigen, 1830.}

Finland. Al: Eckerä, Finsträm, Hammarland, Jomala, Lemland. $A b$ : Dragsfjärd, Karjalohja, Lohja, Nauvo, Turku. $N$ : Helsinki, Kirkkonummi, Porvoo, Tvärminne. Om: Pietarsaari. $O b$ : Oulu. Total $320^{\circ} 0^{\circ}, 17$ ㅇ․

Russia. $K r$ : Impilahti, Derevjannoe. Total $1 \sigma^{7}, 1$ \&.

Adults from the end of June to the beginning of August on dry meadows. Small sized species (no more $2.5-3 \mathrm{~mm}$ ), very similair to $C$. troglodytes. It may be separated from $C$. troglodytes by predominantly yellow abdomen, wide lateral ridges, more obtuse fore corner of frontal triangle, yellow basal segments of antennae and male genitalia (Fig. 27).

Euro-asian boreal species; known from Sweden to Bulgaria and from Britain to the south of Siberia.

\section{Chlorops centromaculatus (Duda, 1933).}

Finland. N: Helsinki, 2.VIII.-21.IX.1976, 23.VIII.1977 (Koponen). Ta: Kärkälä 15.VIII.1979 (Koponen). Total 2 ๑ొ0, 2 우.

New species for Finland. It seems to be an autumnal species. The species is easily distinguished by long palpi, yellow frontal triangle with small black spot around ocelli, shining black stripes on scutum.

European: so far known only from Central Europe (Germany, Austria, Switzerland, Hungary, North Italy).

\section{Chlorops citrinellus (Zetterstedt, 1848).}

Finland. Ta: Hämeenlinna.

The species was earlier recorded for Finland as $C$. bipunctus Duda. I have no additional material. I have seen only $10^{7}$ lectotype of $C$. bipunctus Duda, N 8159, designated by Zuska (1960) with labels: "Tavastia, Palmen", "Oscinis geminata Meig. Bonsd. det." and "Oscinis bipunctifrons var. fennica 9 Typus" (handwriting by Duda, bipunctifrons is error). I have failed to find another female mentioned by Duda with label "Teisko R. Frey, 6964". Rare species, e.g. only 1 female is known from St. Petersburg region (southern part, Luga), where Chloropidae have been collected for many years, and a few specimens are known from Estonia (see below).

European species, known from southern Sweden to "Südsteiermark".

\section{Chlorops crassipalpis Smirnov, 1958.}

Finland. $N$ : Helsinki (Ahnger) 1 \%

New species for Finland. The species is easily distinguished by long thick palpi blackish at tip, dull grey pollinose stripes on scutum, reddish-yellow spot on katepisternum, yellow abdomen and long female cerci.

Rare East Euro-kazakhstanian species, so far known from Latvia, Moscow oblast and Kazakhstan. 


\section{Chlorops distinguendus Frey, 1909.}

Finland. Al: Finsträm (R. Frey) type-specimen N 4354, 1 \%, Sund (R. Frey) 1 O. $A b$ : Korpo Jurmo, 4.VIII.1960 (M. Meinander) 1 ㅇ․ $N$ : Helsinki Linna (R. Frey) $1 \sigma^{\circ}$. Oc: Bergä, 17.-28.VI.1946 (Hellen) 1 o'. Total $20^{\circ} 0^{7}, 3$ 우.

The species is easily distinguished by extremely narrow gena, large first flagellomere of antennae and form of frontal triangle, with nearly parallel sides in basal part.

Frey described the species in the genus Chlorops wherefrom it was transferred to the genus Assuania Becker (Duda 1933, Zuska 1959). In my opinion the species belongs to the subgenus Asianochlorops Kanmiya, which so far includes two species, C. lenis Becker from Japan and Taiwan and $C$. leymi Nartshuk from the Far East of Russia and Japan. This subgenus is characterized by narrow gena, the arrangement of gonitae in line in contrast to other species of Chlorops with parallel situated post- and pregonites and very probably must be considered as a separate genus. The subgenus Asianochlorops is recorded for Europe for the first time.

The species is known only from Finland: Aland Islands and SW costal areas. Endemism on this territory is known also for a species of beetle Macroplea pubipennis Reuter (Coleoptera, Chrysomelidae) (H. Silverberg, personal communication). There are also some endemic species and subspecies for the territory including South Sweden, Estonia and islands near the Karelian Isthmus. I know of the following cases - Auchenorrhyncha: Cixidia confinis Zetterstedt, Cosmotettix evanescens Ossiannilsson (the latter species was recently found on the Island of Bolshoy Beresovyy; A. F. Emeljanov, personal communication), Acrididae: Chortippus brunneus brevis Klingstedt, Diptera: Ephydra macellaria alandica Frey (Frey 1909, Wirth 1975, Ossiannilsson 1978-1983, Cogan 1984, Podgornaya 1984). Wirth (1975) considered E. macellaria alandica as subspecies which was "isolated in postglacial time from $\mathrm{ma}$ cellaria in the more brackish water of the shores of the Baltic sea" (p. 32).

\section{Chlorops geminatus Meigen, 1830.}

Russia. Kr: Ruskeala, 28.VII.1949 (Nyland) 1 ․

This species and $C$. zonulatus are very similair to each other. They may be separated by the structure of frontal triangle which is more long and shining in $C$. geminatus and the structure of male genitalia. C. geminatus has longer surstyli and rounded base of phallus (Fig. 21). Not really found in Finland, all specimens under this name in the collections proved to belong to $C$. zonulatus and the species has to be deleted from the list of Finnish Chloropidae. But the species is expected to be found in South Finland. The nearest location, apart from Karelia, is situated on the Island of Saaremaa in Estonia, where the species was collected on the grass Brachypodium pennatum in forests. In the St. Petersburg region the species was known only from southern the part, near Luga.

Eurasian temperate species, known from Sweden to Italy and across southern Russia to East Siberia and Mongolia. Specimens from Japan according to drawings of male genitalia (Kanmiya 1978,1983 ) belong to C. kirigaminensis Kanmiya. I do not agree with the synonymy of the latter species with $C$. geminatus.

\section{Chlorops gracilis Meigen, 1830.}

Finland. $A b$ : Bromarv, Karjalohja, Kimito, Sammatti, Uusikaupunki. $N$ : Espoo, Hanko, Helsinki, Tenhola, Tvärminne. St: Pori, Yläne. Ta: Lammi. Sa: Rautjärvi. $T b$ : Keuruu. $K b$ : Liperi. Total $33 \sigma^{2}, 25$ OQ.

Russia. Kr: Tivdia, 107.

Adults from the end of June to the middle of August. Larvae develop in stems of Calamagrostis epigeios. Flies are usually collected on this grass on sandy places. The largest species in the genus (body long 5-6 mm). Body is light yellow. Frontal triangle very short, yellow.

Euro-asian temperate species, known from Sweden to Bulgaria, eastward to Kazakhstan, the Altai and Mongolia.

\section{Chlorops hypostigma Meigen, 1830}

Finland. Al: Finsträm, Jomala, Saltvik. $A b$ : Kaarina Kuusisto, Karjalohja, Lohja, Parainen, Uusikaupunki, Vihti. $N$ : Espoo, Helsinki, Inkoo, Kauniainen, Kirkkonummi, Tvärminne. St: Vammala. Ta: Hämeenlinna Vanaja, Kangasala, Sysmä, Tampere. Sb: Kuopio, Maaninka Tuovilanlahti. Om: Uusikaupunki. $O b$ : Liminka. Total $250^{\circ} 0^{\circ}, 33$ 웅․

Russia. Kr: Ruskeala, Kolatselga, Olonetz. Total $20^{\circ} 0^{7}$, 4 우우. 
Adults in June and the beginning of August on meadows and borders of forests. One of the smallest species of the genus, body long $1.5-2 \mathrm{~mm}$. Small dark spot on frontal triangle, larger first flagellomere, narrow gena and more shining scutal stripes separate this species from $C$. calceatus.

Euro-caucasian, known from Faroes and Sweden to Spain, Italy, Bulgaria and the Transcaucasus.

\section{Chlorops laetus Meigen, 1830.}

Russia. Kr: Sheltozero, 3.IX.1942 (Tiensuu) 1 오.

Autumnal species. The species is distinguished by dull grey stripes on scutum and dull grey spot on katepisternum; anepisternum with a few black hairs. Not found in Finland, but known from Estonia and St. Petersburg region. The nearest locality: Island of Bolshoy Beresovyy near Vyborg. The species is expected to be found in Finland.

Euro-caucasian, known from Britain and Sweden to Poland and the Causasus.

\section{Chlorops nigripalpis (Duda, 1933)}

Only the type-specimen in known, The specimen is currently on loan in the Zoological Museum of the Lund University in Sweden and I have seen it. The type-specimen is a female with 5 labels: "Car[elia] ross[ica]", "Tengström", "Oscinis nigripalpis Duda $\$$ (Typus) d. Duda" [Duda's handwriting]", red tag without text and printed labels "Duda det." without any other text. The species is not found anywhere, except Karelia. It is necessary to investigate more material to clarify relationships between $C$. nigripalpis and $C$. crassipalpis.

\section{Chlorops obscurellus (Zetterstedt, 1838).}

Finland. Oa: Lapua, Ylistaro. $K b$ : Polvijärvi. Om: Lappajärvi, Pietarsaari. Total $60^{7} 0^{7}, 3$ 우.

Adults from June to August. The species is distinguished by entirely black polished frontal triangle with wrinkled broad apex and wide thick grey pollinose stripes on scutum which are sometimes nearly fused and darkened scutellum.
Euro-asian boreal species; known from Norway and Swedish Lapland to Austria and Belorussia, eastward to Yakutia.

\section{Chlorops planifrons Loew, 1866.}

Finland. $A l$ : Finsträm. $A b$ : Kaarina Kuusisto, Korpo Jurmo, Parainen, Turku, Vihti. N: Hanko, Helsinki, Kirkkonummi, Porvoo, Tenhola, Tvärminne, Vantaa. St: Yläne. Ta: Tampere. Sa: Lappeenranta Hannijärvi, Rajala (Saima Kanal). $O a$ : Petolahti. Sb: Kiuruvesi, Maaninka Tuovilanlahti. Om: Lohtaja, Pietarsaari, Uusikaupunki. Ok: Puolanka Tulijoki, Suomussalmi. $O b$ : Hailuoto, Liminka, Oulu. $L k$ : Muonio, Sodankylä. Li: Inari Kaamanen, Lemmenjoki. Total $410^{\circ} 0^{\prime}$, 47 우.

Russia. Kr: Kem, Segezha. Total 2 фo. Lr: Yläluostari, Salmijärvi, Pechenga, Lutto, Kola. Total 3 ơơ, 5 우.

Adults from the end of June to the middle of August on bogs and marshes. Larvae develop in stems of Carex inflata and apparently in other large species of Carex. The species is very variable in colour. Frontal triangle from entirely black to yellow with two black spots: one around ocelli and another nearly rhomboid black spot in apical part. Spot on katepisternum from black to yellow. More light coloured specimens were described as C. triangularis Becker, 1910, but some specimens have yellow spot on katepisternum and dark frontal triangle and vice versa. Thus, $C$. triangularis cannot be considered as a separate species. The species is distinguished by whitish arista, black first flagellomere and yellow basal segments of antennae, rather narrow grey pollinose stripes on scutum. Females are easily distinguished by long cerci of ovipositor, distant in dry specimens in the collections.

I have not seen the type-specimens of $C$. certimus Adams, described from Massachusetts, USA (Adams 1904). I have investigated some specimens and male genitalia from North America (Michigan and Illinois) determined by Becker as C. certimus in the Zoologocal Museum in Berlin. These specimens are coloured as $C$. planifrons var. triangularis and male genitalia is undistinguished from male genitalia of $C$. planifrons.

Holarctic polyzonal species, known from Britain to Far East of Russia and from Lapponia and Yakutia to Spain and Mongolia. In North America from Alaska to Michigan and Illinois. 


\section{Chlorops pumilionis (Bjerkander, 1778).}

Finland. $A l, A b, N, S t, T a, S a, K b, O m$. Total 70 specimens. Krogerus (1960) recorded this species for Kuusamo, but I have seen no specimens from that territory.

Russia. Kr: Soutjärvi, Petrosavodsk, Salmi, Sortavala, Jaakkima, Santama, Gizhino, Olonez. Total 17 specimens.

Adults from the end of May to the end of September, two generations. Larvae develop in stems of grasses of the genera Roegneria, Triticum, Aegilops and others. The species is rather variable in colour. Frontal triangle from entirely black to almost yellow with black spot around ocelli and black middle line. Structure of frontal triangle is specific: from fore ocellus to the top there is a groove which transforms into a low ridge in apical part of triangle. Basal segments of antennae, apical part of fore tibia and fore tarsus usually darkened. Abdomen usually black dorsally. Stripes on scutum and spot on katepisternum are covered by thick grey pollinose.

Euro-asian temperate species, widespread from North Europe to Israel, Iran, West Siberia and Mongolia.

\section{Chlorops ringens Loew, 1866.}

Finland. $A b$ : Lohja, Turku, Uusikaupunki. $N$ : Ekenäs, Elimäki, Helsinki, Tvärminne. Ka: Hamina. Sa: Joutseno. Total $90^{\circ} 0^{n}, 15$ 우우.

Autumnal species, adults from the middle of August to middle of September. The species is distinguished by long palpi, usually darkened at tip in female, reddish-yellow spot on katepisternum and grey arista. Frontal triangle black with light spots before fore ocellus and laterally from hind ocelli, the latter spots separate frontal triangle from dark occipital spot.

Euro-asian temperate species, known from South Finland to Bulgaria and eastward to East Siberia (Yakutia).

\section{Chlorops rossicus Smirnov, 1955.}

Finland. $A b$ : Pohja (R. Frey) 1 ㅇ. St: Säkylä, 13.VI.? 1 ㅇ. Tb: Jyväskylä, 15.-17.VI.1947 (F. Hackman) 1 ․ Kb: Pyhäselkä Hammaslahti, 1.VII.1938 (P. Kontkanen) 1 ㅇ. Li: Utsjoki (R. Frey) 10 .
Russia. Lr: Salmijärvi, 28.VI.1937 (Nordman) $10^{7}$; Voron (Häyrän) 10 '.

East European species, known from European part of Russia.

\section{Chlorops rufescens Oldenberg, 1923.}

Finland. $A l, A b, N, S t, T a, S a, K l, O a, T b, S b, K b, O m, O k$, $O b, K s, L k, L e, L i$. Total 203 specimens.

Russia. Kr: Sortavala, Harlu, Salmi, Velikaja Niva, Ruskeala, Impilahti, Kostomuksha, Petrosavodsk, Medvezhjegorsk, Gizhino, Kartesh, Paanajärvi. Total 33 specimens. Lr: Kandalaksha, Kuolajärvi, Murmansk, Seitjaur, Salmijärvi, Ponoj, Yläluostari, Voronje, Pummanki, Pechenga, Trifona, Kuvernääri, Kolttakängas. Total 30 specimens.

Adults from June to the beginning of August, most of the specimens being collected in July. Larvae develop in stems of Calamagrostis species (except $C$. epigeios) grown on wet places on meadows and in forests. The species is distinguished by grey wings, small first flagellomere of antennae and wide polished stripes on scutum. The colour is rather variable. First flagellomere from yellow, darkened and entirely black especially on outer side. Frontal triangle black in middle and narrow or wide yellow along lateral sides. Apex of triangle always yellow, sometimes black only ocellar tubercle and median line. Spot on katepisternum entirely yellow or brown along upper margin. Number of notopleural bristles variable 1(2) + (3-4). Specimens from North Finland and the Kola Peninsula usually dark coloured, stripes on scutum are nearly fused. Dark coloured specimens are rather similair to dark coloured specimens of $C$. speciosus, but male genitalia of these species (Figs. 22-25) are well distinguished and this enables these species to be identified with certainly. Additional specific character of $C$. rufescens - costal vein markedly goes behind vein $\mathrm{R} 4+5$. Investigations of male genitalia are necessary to distinguish dark coloured specimens of C. rufescens from dark coloured specimens of C. speciosus, collected in the North. One of the most numerous and common species in the Finnish collections, was recorded as $C$. meigenii Loew (nom. preoccup.) in Check-list (Hackman 1980). Widespread in Finland, Karelia and the Kola Peninsula.

Transpalaeartctic boreal species; known from 
Lapland to Bulgaria, Kazakhstan and Mongolia and from Britain to Kamchatka and Japan.

\section{Chlorops rufinus (Zetterstedt, 1848).}

Finland. Al: Aland, Mebers. Ta: Tampere, Hauho. Total $2 \sigma^{\circ} \sigma^{\prime \prime}$ 2 우우.

Russia. Kr: Paanaj_rvi, 1 a.

The species is easily distinguished by red stripes on scutum, whitish arista and yellow frontal triangle with two black spots: on ocellar tubercle and at the top, connected by black line.

Rare transpalaearctic temperate species, widespread from Sweden to Japan (Hokkaido) and southward to Bulgaria and Mongolia.

\section{Chlorops scalaris Meigen, 1830.}

Finland. $A l, A b, N, K a, T a, S a, O a, T b, S b, K b, O m, O k, O b$. Total 32 ơ O', 59 우.

Russia. Kr: Kolatselga, Sortavala, Jalguba, Valaam, Impilahti, Padany, Konchozero, Voknavolok. Total $50^{70} 0^{\prime \prime}, 8$ 우.

Adults from the beginning of June to the middle of August. The species is distinguished by long palpi and black spot on katepisternum. First flagellomere of antennae from yellow to black, especially at upper part. Frontal triangle with central black spot and wide yellow lateral sides, sometimes only ocellar tubercle and median line are black. More common in South Finland, spread northwards to Rovaniemi.

Euro-asian polyzonal species, known from Sweden to Italy and Bulgaria and eastward to East Siberia and Mongolia.

Chlorops scutellaris Zetterstedt, 1838.

= Chlorops laevicollis Becker, 1910 - syn. nov. = Oscinis freyi Duda, 1933.

Finland. Kl: Parikkala (J. Sahlberg) 1 ( (det. Duda as Ch. freyi). $S t$ : Yläne (J. Sahlberg) 1 Q , lectotype of Chlorops freyi Duda, designated here. $T a$ : Kangasala (R. Frey) 1 \%, paralectotype, designated here, without abdomen, $S b$ : Maaninka Tuovilanlahti (Lundsträm, Palmen) 1 ơ, 1 \%. Ks: Kuusamo, 19.VII.1934 (Krogerus) 3 우. Lk: Muonio (R. Frey) 2 우. Le: Enontekiä Saana, Lapponia (J. Sahlberg), 1 paralectotype. Total $10^{\circ}$, 11 우.
Russia. Kr: Kuolajärvi, 27.VII.1934 (Krogerus), 1 ․ $L r$ : Khibiny, 1 \%

C. scutellaris was described by Zetterstedt, 1838 from Lycksele, Sweden. Female type-specimen was revised by Andersson (1966). C. laevicollis as described by Becker (1910) from Burjatia (East Siberia, Russia ), male type-specimen was revised by Nartshuk (1970). Oscinis freyi was described by Duda (1933) from Finland as "Freyi sp. nov. vel var. speciosae Mg." Andersson (1966) considered $C$. freyi as a synonym of $C$. scutellaris, but the type-specimens of $C$. freyi were not revised in detail and no lectotype was designated.

This is necessary and is done here because Duda's syntypes series of $C$. freyi contain two species. Duda listed 5 specimens: 2 Ơం $^{\circ}, 3$ 우, in his description. A male from Kola is currently on loan in the Zoological Museum in Lund. I have seen it in 1997, when I visited Lund. The male has 6 labels: "Kola", "Frey", "6901" on rose tag, "spec. typ. 8154", red labels without text and "speciosus var. Frey n. var. d.Duda. Typus". Another male has 3 labels: "Muonio R. Frey, 3122", "speciosa var. Freyi O', d. Duda. Paratype übergangen speciosa" [Duda's handwriting]" and "sp. typ". It is dark specimen of $C$. rufescens: scutal stripes nearly fused, but lateral ones are a little separated in front of scutum, and marginal stripes are well separated, scutellum yellow, the second segment of antennae brownish and palpi darkened; the male genitalia were investigated.

Three females have following labels: "Kangasala, R. Frey 750” (in Duda's description erroneously Kangala), "sp. typ 8157"; "Lapponia Y. Sahlberg, 899" "sp. typ 8155"; "Yläne 299 J. Sahlberg", "sp. typ. 8158 " and all three females are C. scutellaris, although female with number 8155 has more broad gena than the other specimens.I have seen the typespecimens of $C$. scutellaris and Swedish material of the species in Lund and I have compared these specimens with the type specimen of C. laevicollis and found that they are conspecific. The male type-specimen of $C$. laevicollis has darkened scutellum, but all specimens of C. scutellaris investigated by me have yellow scutellum. C. scutellaris is distinguished from dark coloured specimens of C. speciosus and C. rufescens by smaller size, more polished scutum, narrower gena and structure of male genitalia (Figs 15 and 16). 
North Eurasian boreal species; more likely of Siberian origin; known from North Europe and Siberia eastward to Yakutia.

\section{Chlorops serenus Loew, 1866.}

Finland. Al: Käkar, 11.VI.1978 (M. Koponen) 1 \%, Lemland Apalholm, 12.-24.VIII.1954 (H. Lindberg) 1 O’, 1 \%. Total 3 specimens.

New species for Finland. The species is distinguished by dull grey stripes on scutum, wide gena, black first flagellomere, yellow basal segments of antennae and yellow spot on katepisternum. Black spot on frontal triangle rather small, often with yellow windows, lateral sides of triangle wide yellow.

Abdomen yellow with narrow black bands.

Euro-mediterranean species; known from Britain and South Finland to Israel and Algeria.

\section{Chlorops speciosus Meigen, 1830.}

Finland. $A l, A b, N, K a, S t, T a, S a, O a, T b, S b, K b, O m, O k$, $O b, K s, L k, L e, L i$. Total 403 specimens.

Russia. Kr: Sortavala, Harlu, Padany, Chupa, Keret, Vidlitza, Olonetz, Varsuga, Vedlozero, Konchozero, Kolatselga,Petrosavodsk, Valaam, Kirjavalahti, Paanajärvi, Voknavalok. Total 28 specimens. Lr: Pechenga, Yläluostari, Pummanki, Kandalaksha, Ponoj, Salmijärvi, Vuoremi, River Nota, River Tuloma, Murmansk, Polamyi, Varsuga. Total 343 specimens.

Adults from the beginning of June to the end of August. Larvae develop in stems of Deschampsia caespitosa. The most common and numerous species in Finland. The species is distinguished by shining stripes on scutum, entirely black frontal triangle, without yellow along lateral sides but sometimes with dark yellow windows. Dark coloured specimens sometimes have several black hairs on anepisternum along hind side. Entirely black frontal triangle and spot on katepisternum separate this species from rather similar C. rufescens. Structure of male genitalia distinguishes these species as well (Figs 22-25). Specimens from North Finland and the Kola Peninsula are dark coloured: basal segments of antennae black, stripes on scutum wide and nearly fused. Such dark specimens sometimes have 2-3 black hairs on hind margin of anepisternum and 3 hind notopleural bristles instead of usual 2. Rather rarely tip of palpi and legs partly darkened. Dark coloured specimens are distinguished from C. scutellaris by broad gena, structure of frontal triangle, more haired and punctured scutal stripes, which sometimes very thin pollinose. Structure of male genitalia of these species is well distinguished (figs 15 and 16, 24 and 25). Some specimens of $C$. speciosus are very large $(6-7 \mathrm{~mm})$; some of them were labelled "major Frey" or " $g i$ gantea sp. n." by R. Frey in the collection. These names were not published. Most of the specimens in the collections are female, except one male from Saltvik, and it does not differ, except in size, from typical specimens of $C$. speciosus. They were collected on Aland Islands and in southern parts of Finland ( $A l$ : Käkar, Fäglä, Saltvik. Ab: Nauvo, Uusikaupunki, $N$ : Hanko, Helsinki). Large specimens can also be collected in St. Petersburg region.

Frey (1933) mentioned one specimen of C. pallifrons Strobl for Finland. In next paper (Frey 1941) he mentioned var. pallifrons of C. speciosus. Hackman (1980) did not mention C. pallifrons at all. I have seen a female labelled "Kuusamo J.E. Aro" which is currently on loan in the Zoological Museum of the Lund University in Sweden. It is the same specimen which was determined as $C$. pallifrons by O.Duda and was mentioned by Frey (1933). This specimen is a light coloured specimen of C. speciosus. Species C. pallifrons Strobl is another good species.

Euro-asian boreal species; known from Norway and the Kola Peninsula to Spain and Bulgaria and from Ireland eastward to the Altai in West Siberia.

\section{Chlorops troglodytes (Zetterstedt, 1848).}

Finland. $A l$ : Eckerä, Käkar, Lemland. $A b$ : Bromarv, Karjalohja, Korpo Jurmo, Nauvo, Perniä. $N$ : Espoo, Hanko, Helsinki Sveaborg, Kirkkonummi, Tvärminne. St: Yläne. Ta: Forssa, Hattula, Hauho, Kangasala, Tampere, Teisko, Sysmä. Sa: Joutseno, Rajala (Saima Kanal). $T b$ : Rautalampi. Ks: Kuusamo. Total 33 ơ', 20 우우.

Russia. Kr: Soutjärvi, Chupa, Paanajärvi. Total $50^{7} 0^{\prime}$, 3 우. Lr: Kuolajärvi, 1 ㅇ.

Adults from the beginning of June to the end of August. Small sized species (2-2.5 mm) with dark basal antennal segments and dark abdomen dorsally. It is distinguished from similair C. cal- 
ceatus by black frontal triangle, at most only narrowly yellow along lateral sides, more acute fore corner of triangle, dark abdomen dorsally and structure of male genitalia (Fig. 26).

Euro-asian boreal species; known from Norway and Britain to Bulgaria and eastward to Yakutia and Mongolia.

\section{Chlorops varsoviensis Becker, 1910.}

Finland. $A l$ : Finsträm. $N$ : Tammisaari, Tvärminne. $S b$ : Maaninka Tuovilanlahti. $K b$ : Eno (Gränvik). $O m$ : Vimpeli. $O b$; Rovaniemi Pisavaara naturpark. Ks: Kuusamo. Lk: Sodankylä. Le: Enontekiä Malla. Total $11 \sigma^{\prime}, 17$ 우. 3 우.

Russia. Kr: Ruskeala, Salmi. Lr: Kuolajärvi. Total $20^{\circ} 0^{\circ}$,

Adults from the beginning of July to the middle of August. Larvae develop in stems of Carex and the species is usually collected on bogs and marshes with Carex. The species is distinguished by narrow gena, white or black hairs on anepisternum, short fore metatarsus and asymmetrical claws of fore legs in male. Abdomen is reddish brown in female, and from light yellow to dark dorsally in male. Antennae and palpi are variably coloured: from yellow to black.

Transpalaearctic polyzonal species; known from France to Japan, southward to Spain, North Italy, Bulgaria, Transcaucasus and Mongolia.

\section{Chlorops zernyi (Duda, 1933).}

Euro-asian boreal species; known from Austria to Far East of Russia. The species is common in Asian part and very rare in European part of range. Only a few specimens are known previously from Europe: 1 from Austria (Duda 1933), 1 from Gobzhiza near Luga in St. Petersburg region (Stackelberg 1958) and 2 ơ $^{7}, 4$ 우 on Karelian Isthmus (Nartshuk 1962). There is one more female in the investigated material, collected in Syväri Uslanka, in the northeastern part of the St. Petersburg region near the border with Karelia. The species is expected to be found in Finland and in Karelia. Larvae develop on Carex. The species is distinguished by white arista, darkened tip of palpi, dull grey, rather narrow stripes on scutum, broad cerci of ovipositor. The last character clearly dis- tinguishes this species from C. planifrons.

\section{Chlorops zonulatus Wahlgren, 1913}

Finland. $A l$ : Eckerä, Hammarland. Ab: Nauvo, Vihti. $N$ : Tvärminne. Ta: Hattula. Kl: Parikkala. Sb: Savon. bor. Ks: Kuusamo. Total $100^{\prime}, 10$ 우우.

Russia. Kr: Paanajärvi, $1 \sigma^{\prime}$.

New species for the Finnish fauna. All specimens in the Finnish collection were previously determined as $C$. figuratus or C. geminatus. Adults in June and July. Larvae develop in stems of Hierochloe odorata (observation in Moldavia).

The species is separated from C. geminatus by the frontal triangle, which is swollen laterally and has some black spots. These two species are clearly distinguished by structure of male genitalia as well (Figs. 20, 21).

Transpalaeartctic boreal species; known from Sweden to Moldavia and eastward to Far East of Russia and Mongolia.

\section{Epichlorops puncticollis (Zetterstedt, 1848).}

Finland. $A l$ : Aland. $A b$ : Korpo Jurmo, Uusikaupunki. $N$ : Helsinki Sveaborg, Tvärminne. St: Yläne. Ta: Hattula, Heinola, Teisko. Oa: Lapua. Om: Yxpila. Total $90^{7}, 9$ ㅇ․

Russia. Kr: Suistamo, 1 \%.

Adults in July and August, collected on bogs and marshes with Carex.

Holarctic species, in Palaeartctic occurs from Sweden to Japan, southward to Kazakhstan and Mongolia.

\section{Melanum laterale (Haliday, 1833).}

Finland. $A l$ : Eckerä, Fäglä Bänä. $A b$ : Dragsfjärd, Kaarina Kuusisto, Korpo Jurmo, Nauvo. N: Ekenäs, Espoo, Hanko, Helsinki, Porvoo, Tenhola, Tvärminne. Om: Pietarsaari. $O b$ : Hailuoto, Kuivaniemi. Total 35 ơ 0 , 36 ○․

Russia. Kr: Shuja, 1 ㅇ․ Lr: Ponoj, 1 우.

Adults from the beginning of June to the middle of August, on shores of lakes, banks of rivers, and on sea shore.

Transpalaeartctic polyzonal species; occurs from Ireland to Japan, southward to Spain and China. 


\section{Additions to lists of Chloropini for Estonia and St. Petersburg region, and some new records of rare species.}

I think it is relevant to give the following short list here, because it contains the most northern records of some species in Europe and these species are included in the key proposed in this paper.

\section{Chlorops citrinellus Zetterstedt, 1848.}

Estonia: Tartu, 26.VII.1960 (Elberg), 1 ơ.

Rare species, was previously known mostly from western part of Estonia (Nartshuk \& Elberg 1979).

\section{Chlorops figuratus Zetterstedt, 1848.}

Estonia: Island Saaremaa, Valjala, 22.VII.1987 (Nartshuk), 3 ơ $^{7}, 5$ 우우.

Euro-asian boreal species; known from South Sweden southward to Hungary and Croatia.

\section{Chlorops frontosus Meigen, 1830.}

Estonia: Island Saaremaa, Nature Reserve Viidumae and Rannakula. End of May-beginning of June (Elberg), 3 specimens.

European species; known from Britain to Poland and Italy. This record is the most northern locality of this species. Records previously from Eastern Europe: Lipetzk and delta of River Volga.

\section{Chlorops novakii Strobl, 1902.}

Estonia: Varblast, 25.VII.1976 (Remm), 1 ㅇ.

Transpalaearctic species; from Central Europe to Far East of Russia and Mongolia, but mainly in southern parts of Palaearctic. This record is the most northern locality. The species is not found in the St. Petersburg region.

\section{Chlorops pannonicus Strobl, 1893}

Estonia: Island Kyinastu, 21.VII.1987 (Nartshuk), Island Saaremaa, Viidu, 28.VII.1987 (Nartshuk). Total 3 070".

Transpalaearctic species; known from Central Europe to Far East of Russia and Mongolia, but mainly from southern parts of Palaerctic. These records are from the most northern localities. In the St. Petersburg region this species is found only in the southern part: environs of Luga (Stackelberg 1958).

\section{Chlorops rufinus Zetterstedt, 1848.}

Estonia: Island Saaremaa, Nature Reserve Viidumae, 30.VII.1987 (Nartshuk), Island Kyinastu, 21. VII.1987 (Nartshuk). Total $20^{\circ} 0^{\prime}, 1$ ㅇ.

Rare species, only one female previously known from Peedu in Estonia (Nartshuk \& Elberg 1979). Distribution is recorded in the list for Finland.

\section{Chlorops strigulus (Fabricius, 1794).}

Estonia: Haapsalu, 25.V.1990 (M. Koponen), 1 ․ One ơ previously recorded also from vicinity of Haapsalu (Elberg 1963).

Rather rare species, known from Europe, including Eastern Europe, the Transcaucasus and southern Siberia. Records from Estonia represent the most northern locality this species.

\section{Chlorops zonulatus Wahlgren, 1913}

Estonia: Island Saaremaa, Kubasary, 22.VII.1987 (Nartshuk), 4 ơ ơ.

Russia: St. Petersburg region: Beloostrov, 15.VIII.1956 (Nartshuk), Tolmachevo, 22. VII.1960 (Nartshuk). Total 4 O'0", 3 우.

The distribution is recorded in the list of Finnish species.

Acknowledgments. I think all the staff of the Department of Entomology in the Zoological Museum of the University of Helsinki for their kind and diverse support during 
my research sojoum in Helsinki, especially dipterologists Prof. W. Hackman, Dr. B. Lindeberg, Dr. G. Ståhls and Dr. P. Vilkamaa. Dr. H. Silverberg helped me in interpreting old spellings of place names. Dr. M. Koponen (Department of Applied Zoology at the same university) permitted me to identify some Chloropidae collected by him in Finland and Estonia. I also thank Dr. K. Elberg (Institute of Zoology and Botany, Estonian Academy of Sciences in Tartu) for the loan of some Chloropidae specimens collected by him in Estonia and for inestimable help in organising collected trips to Saaremaa in 1989 and to southeastern Estonia in 1987. Special thanks are due to Dr. H. Ulrich (Zoologisches Forschungsinstitut und Museum A. Koenig, Bonn), Dr. H. Schumann, H. Wendt (Zoologisches Museum, Humbold Universität Berlin), Dr. J. Ziegler (Projektgruppe Entomologie, Eberswalde) and Deutsche Forschungsgemainschaft for the opportunity to investigate the Chloropidae collection, including the type-specimens in German Museums. I am grateful to Dr. H. Andersson (Zoologiska Institutionen, Lund) for specimens of Chlorops scutellaris Zetterstedt and for some valuable remarks on the type specimen of $C$. $z o$ nulatus Wahlgren. This study was carried out using the "Scientific Collections of the Zoological Institute, Russian Academy of Sciences" with financial support from the Ministry of the Russian Federation (Registration No 96-03-16), the State Science and Technology Programme (grant "Biological Diversity") and the Russian Basic Research Foundation (Codes 95-15-97910 and 96-04-48804).

\section{References}

Adams, C. F. 1904: Descriptions of new Oscinidae. - Entomol. News 5: 303-304.

Andersson, H. 1966: Taxonomic and phylogenetic studies on Chloropidae (Diptera) with special reference to Old World genera. -Entomol. Scandinavica. Suppl. 8, $200 \mathrm{pp}$.

Cogan, B. N. 1984: Family Ephydridae. - Catalogue of Palaearctic Diptera, Budapest, 10: 126-176.

Duda, O. 1933: Chloropidae. — In; E. Linder (ed.), Die Fliegen der palaearktischen Region 6(1): 49-248.

Elberg, K. 1963: On some rare species of flies (Diptera), Brachycera) in Estonia. -Eesti NSV Tleaduste Acad. Toimetised, Ser. biol. 12 (4): 345-351. (In Russian.)

Frey, R. 1909: Mitteilungen über finnländische Dipteren. - Acta Soc. Fauna Flora Fennica 31(9): 1-24.

Frey, R. 1933: Färteckning äver Finlands Chloropider, bestämda av O. Duda. — Mem. Soc. Fauna Flora Fennica 9: 128-139.

Frey, R. 1941: Diptera Brachycera. - In: Enumeratio Insectorum Fenniae VI. Diptera. Helsingfors. 63 pp.

Gerasimov, I. P., Baranov A. N., Davitaja F. F. et al. (eds.) 1964: Physico-geographical atlas of the World. Moskwa. 298 pp.

Hackman, W. 1958: The Opomyzidae (Diptera) of Eastern
Fennoscandia. - Notulae Entomol. 38: 114-126.

Hackman, W. 1980: A check list of the Finnish Diptera II Cyclorrhapha. - Notulae Entomol. 60: 117-162.

Kanmiya, K. 1978: Notes on the genus Chlorops Meigen (Diptera, Chloropidae) from Japan and Formosa. Kontyu 46(1): 1-76.

Kanmiya, K. 1983: A systematic study of the Japanese Chloropidae (Diptera). - Mem. Entom. Soc. Wash. 11: 1370.

Kovalev, V. G. 1978: On some interesting records of flies of the family Empididae (Diptera) in Estonia. - Isvestia AN Estonskoy SSR, Biology 74(4): 295-300. (In Russian, English and Estonian summaries.)

Krogerus, R. 1932: Über die ökologie und Verbreitung der Arthropoden der Triebsandgebiete an den Küsten Finnlands. - Acta Zool. Fennica 12: 1-308.

Krogerus, R. 1960: Ökologische Studien über nordische Moorarthropoden. — Comment. Biol. 21(3): 1-238.

Laaksonen, K. 1979: Effective temperature sums and duration of the vegetative period in Fennoscandia (19211950) - Fennia 157: 171-197.

Lindberg, H. \& Saris, N. E. 1952: Insektenfaunan i Pisavaara naturpark (Finland, Prob. Ob.). — Acta Soc. Fauna Flora Fennica. 69(2): 1-82.

Nartshuk, E. 1970: A revision of types of Chloropidae (Diptera) descriped by Th. Becker and O. Duda from the collections of the Zoological Institute of AN SSSR. Entomol. obozrenie 49 (2): 459-470. (In Russian.)

Nartshuk, E. P. 1962: (On fauna and ecology of Chloropidae (Diptera) of Leningrad oblast). - Trudy Zool. Inst. 30: 250-275. (In Russian.)

Nartshuk, E. P. 1984: (Diptera of Bolshoy Beresovyy Islands connected with grasses with description of a new species of the family Opomyzidae). - Trudy Zool. Inst. Leningrad 23: 51-59. (In Russian.)

Nartshuk, E. P. 1992a: (On Chloropidae (Diptera) of northern part of Ural). - Insects in estestvennykh $\mathrm{i}$ antropogennych biozenosakh Urala. Ekaterinburg, pp. 100-102. (In Russian.)

Nartshuk, E. P. 1992b: Chloropid flies of the genus Chlorops (Diptera, Chloropidae) of Yakutia. - Systemtica, Zoogeografia i karyologia dvukrylykh nasekomykh. St. Petersburg, pp. 121-129.

Nartshuk, E. P. 1992c: Revision of the species of Meromyza Meigen (Diptera, Chloropidae) from Finland. - Entomol. Fennica. 3(3): 121-138.

Nartshuk, E. P. 1993: On Opomyzidae (Diptera, Cyclorrhapha) of the Baltic countries, with a revision of Sintenis' collection. - Proc. Estonian Acad. Sci. Biol. 42 (1): $1-12$.

Nartshuk, E. P. \& Elberg, K. 1977: Über die ChloropidenFauna (Diptera) des Sowjetischen Baltikums. - In: Verh. 7 Intern. Symposium of Entomofauna Mitteleuropa. Leningrad, pp. 323-325.

Nartshuk, E. P. \& Elberg, K. 1979: List of Chloropidae (Diptera) of Estonia. - Dipteroloogilisi Uurimus, Tartu: 122-143. (In Russian, with English and Estonian summaries.) 
Ossiannilsson, F. 1978-1983: The Auchenorrhyncha (Homoptera) of Fennoscandia and Danmark. - Fauna Entomol. Scand. 7: 1-979.

Pekkarinen, A., Teräs, I., Viramo, J. \& Paatela, J. 1981: Distribution of bumblebees (Hymenoptera, Apidae: Bombus and Psithyrus) in eastern Fennoscandia. - Notulae Entomol. 61: 71-89.

Podgornaya, L. I. 1984: (Orthopteroid insects of the Island Bolshoy Berezovy). - Trudy Zool. Inst. Leningrad 123: 8-11. (In Russian)

Stackelberg, A. A. 1958: (Material on Diptera fauna of Leningrad oblast. III Diptera Acalyptratae. pt. 1). - Trudy Zool. Inst. Leningrad 24: 103-191 (In Russian.)

Stackelberg, A. A. 1965: (New data on Diptera fauna of
Leningrad oblast). — Latvias Entomologs. 10: 61-71. (In Russian.)

Wilkey, R. E. 1962: A simplified technigue for clearing, staining and permanently mounting small Arthropoda. - Ann. Entomol. Soc. America 55(5): 606.

Wirth, W. W. 1975: A revision of the brine flies of the genus Ephydra of the Old World (Diptera: Ephyridae). - Entomol. Scan. 6: 11-14.

Zetterstedt, J. W. 1860: Diptera Scandinaviae. Disposita et descripta. Lundae, 14: 6191-6609.

Zuska, J. 1960: Bemerkungen über einige palaearktischen Arten der Gattung Chlorops Meigen und Beschreibung einer neuen Art aus Tschechoslowakei (Diptera, Chloropidae). - Acta Entomol. Czechoslov. 57(4): 387-397. 


\section{Appendix}
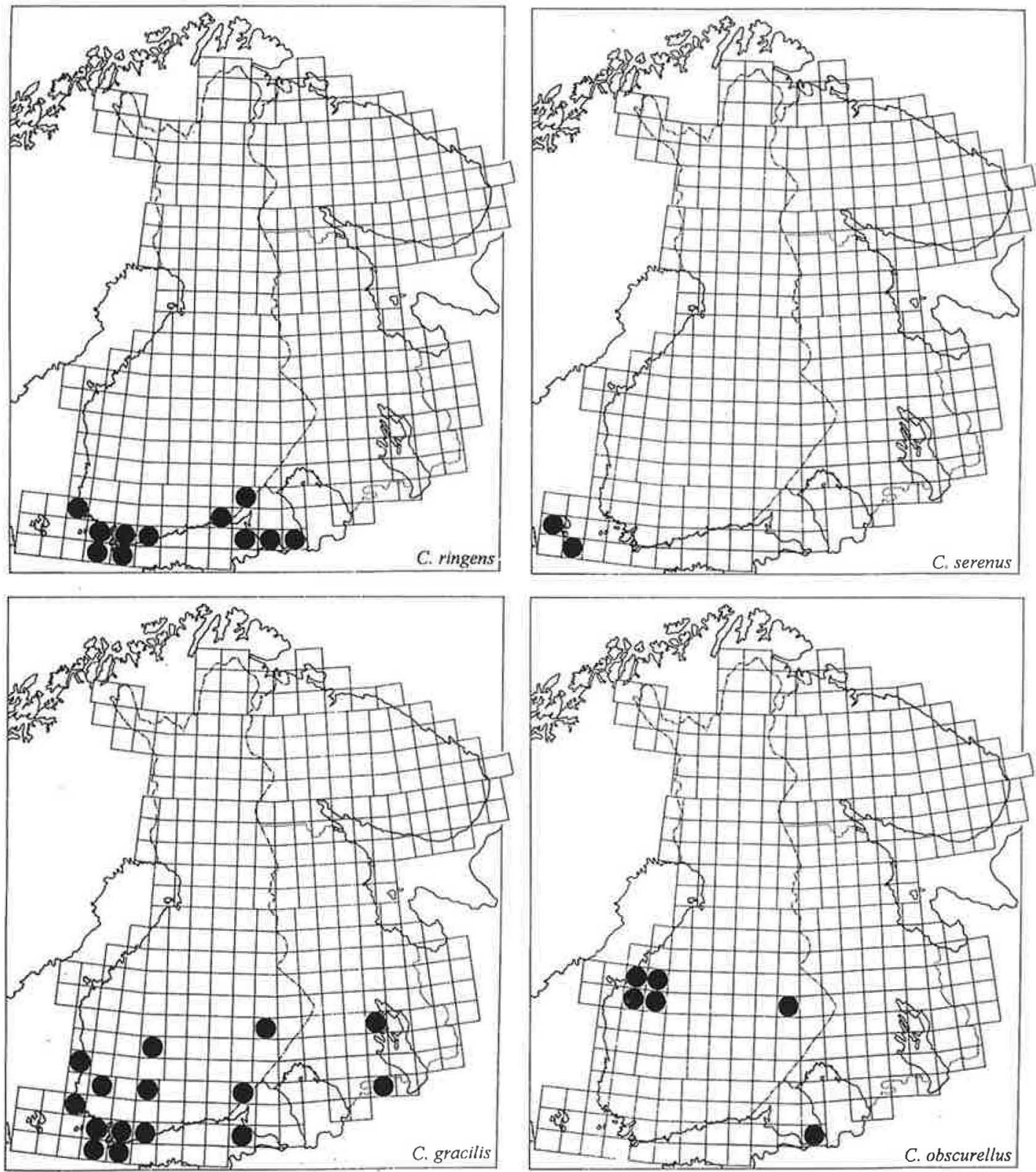
178 Nartshuk: A revision of grassflies of the tribe Chloropini - ENTOMOL. FENNICA Vol. 9
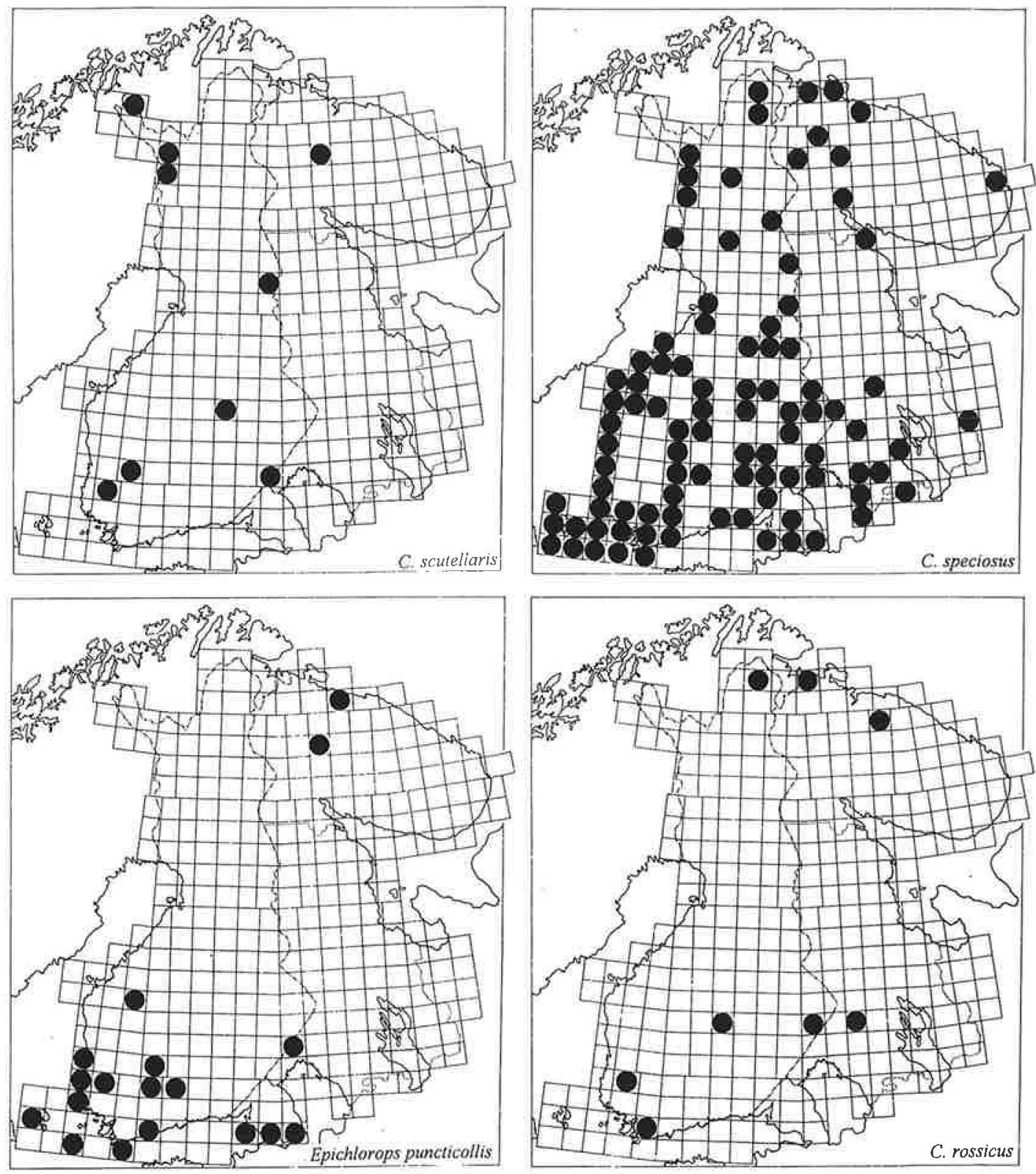

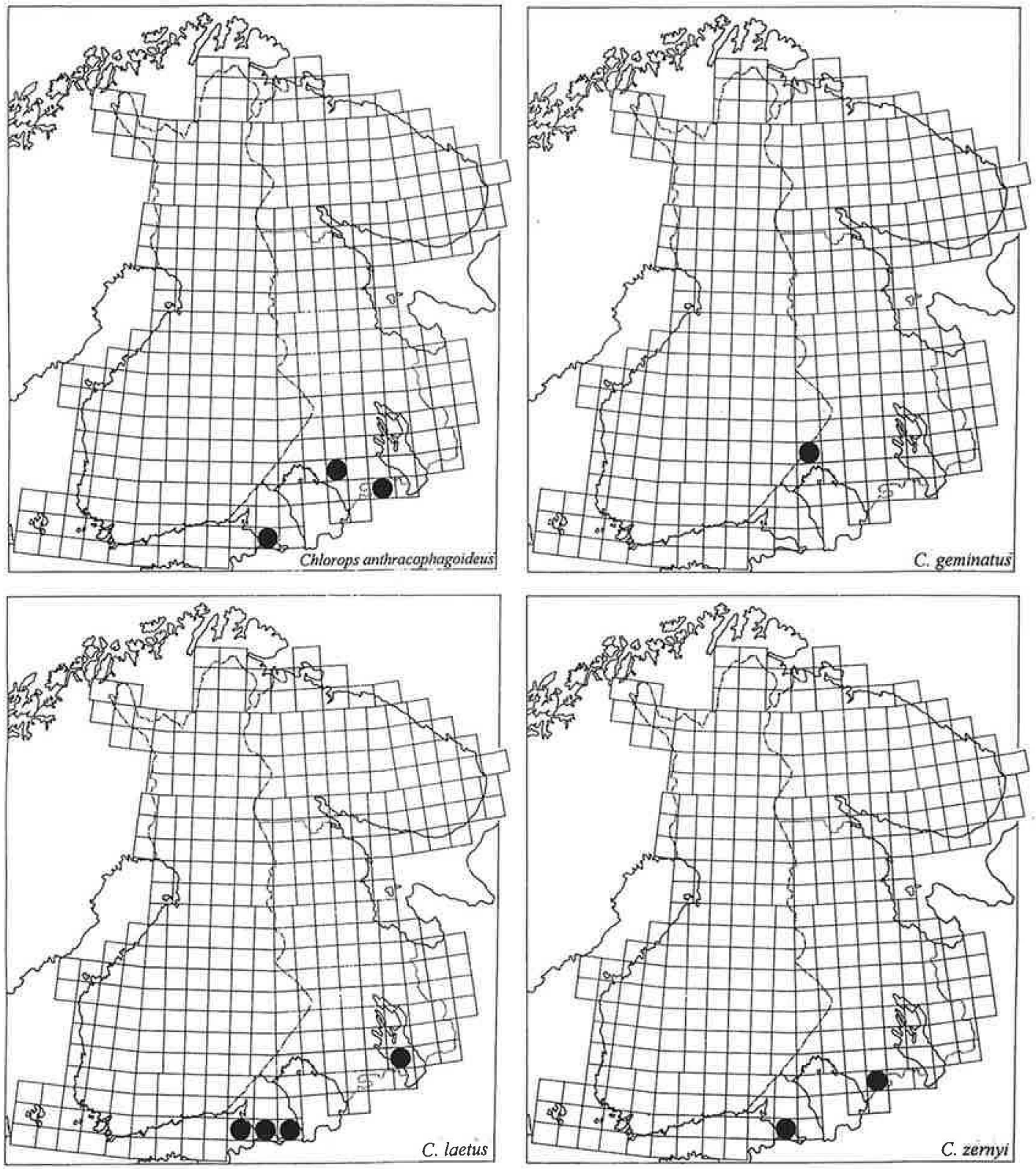

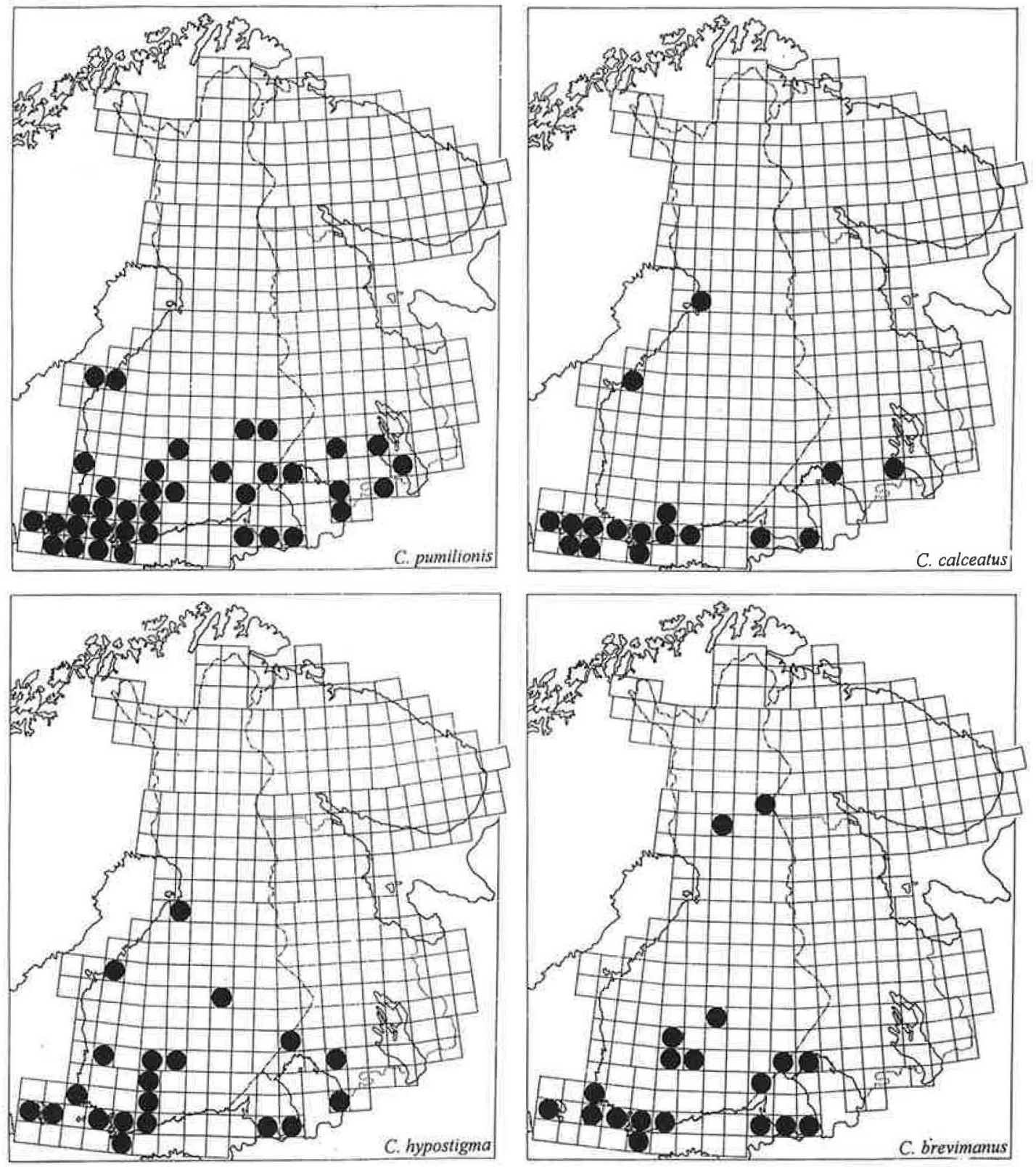

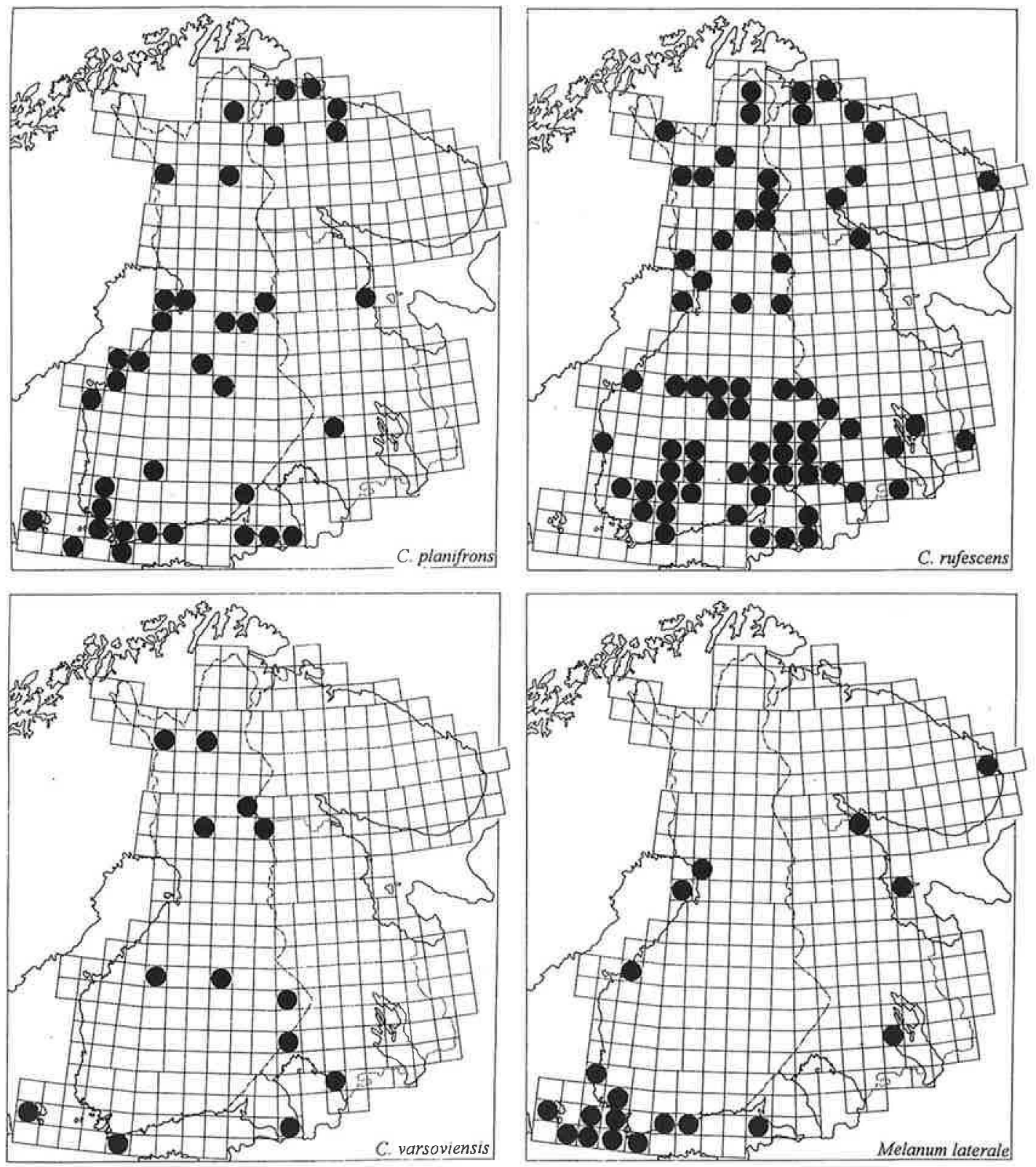

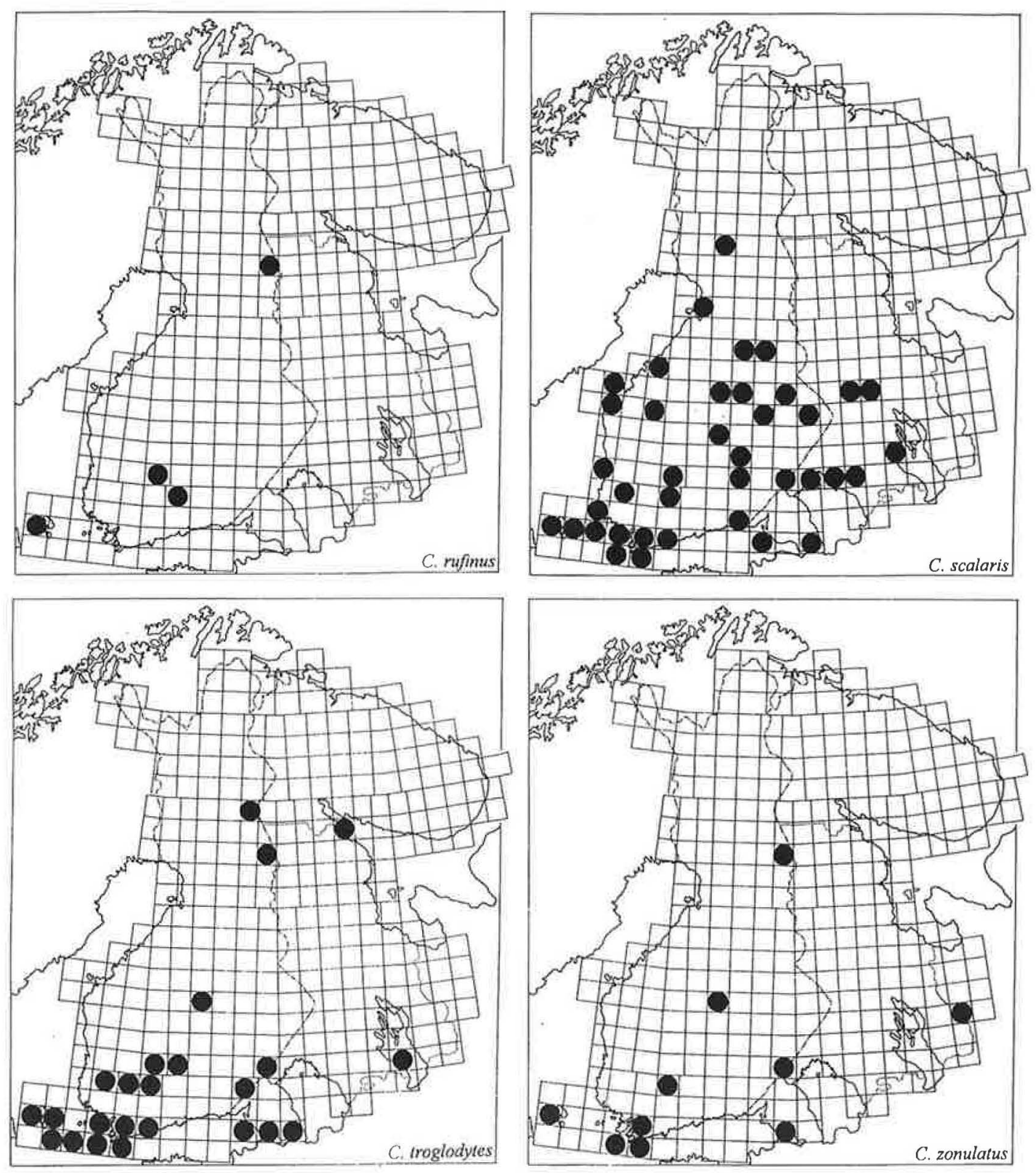

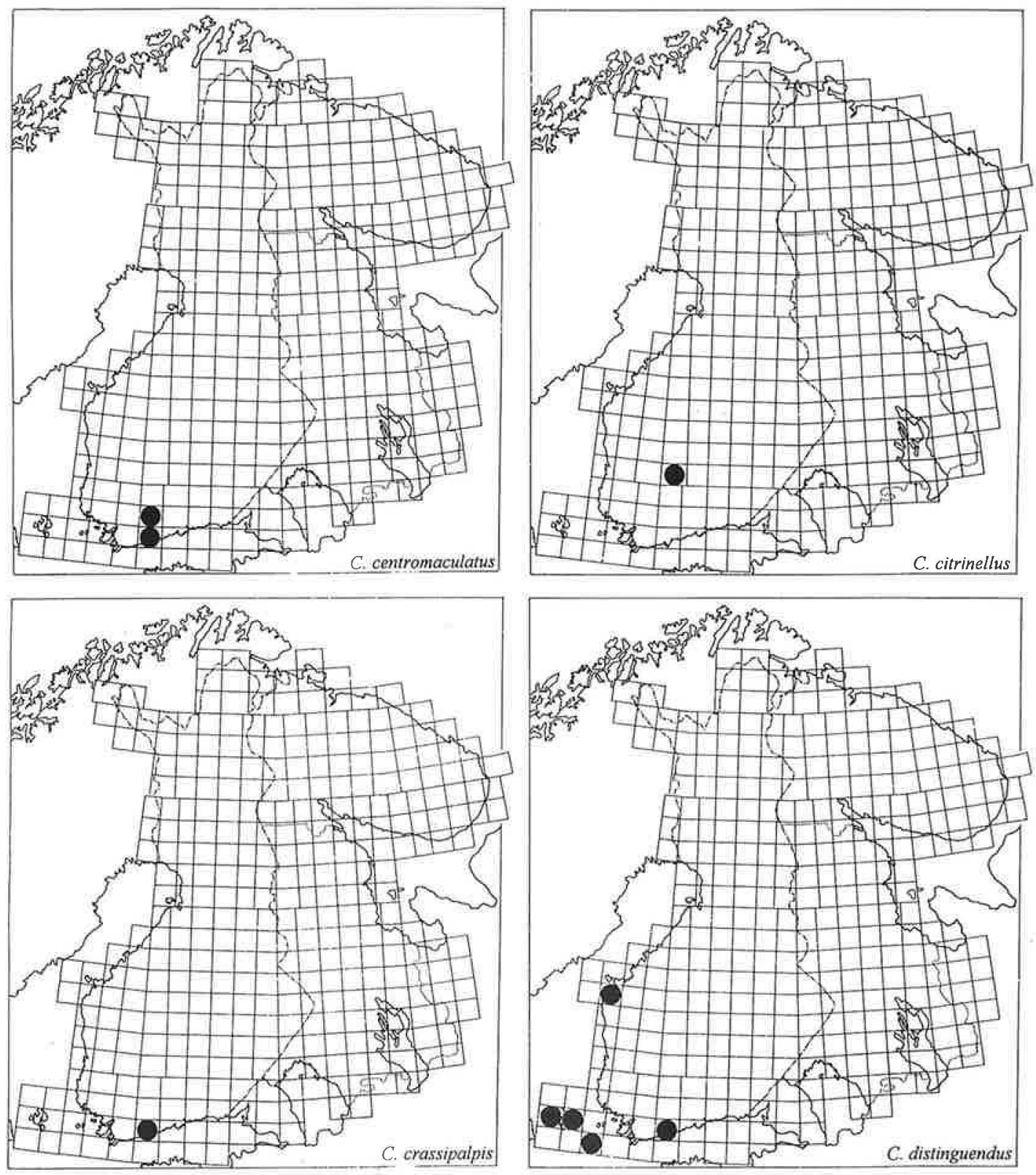